\title{
Factors Influencing Biological Treatment of MTBE Contaminated Ground Water
}

William T. Stringfellow ${ }^{* 1}$, Robert D. Hines, Jr. ${ }^{2}$, Dirk K. Cockrum ${ }^{3}$, and Scott T. Kilkenny ${ }^{3}$

${ }^{1}$ Center for Environmental Biotechnology, Lawrence Berkeley National Laboratory MS 70A-3317, Berkeley, CA 94720.

Phone: (510) 486-7903 Fax: (510) 486-7152 e-mail: wstringfellow@lbl.gov

${ }^{2}$ System Projects and Process Services, USFilter, Envirex Products

1901 S. Prairie Ave, Waukesha, WI 53196

${ }^{3}$ Kinder Morgan Energy Partners

1100 Town and Country Road, Orange, CA 92868

*Corresponding author 


\begin{abstract}
Methyl tert-butyl ether (MTBE) contamination has complicated the remediation of gasoline contaminated sites. Many sites are using biological processes for ground water treatment and would like to apply the same technology to MTBE. However, the efficiency and reliability of MTBE biological treatment is not well documented.

The objective of this study was to examine the operational and environmental variables influencing MTBE biotreatment. A fluidized bed reactor was installed at a fuel transfer station and used to treat ground water contaminated with MTBE and gasoline hydrocarbons. A complete set of chemical and operational data was collected during this study and a statistical approach was used to determine what variables were influencing MTBE treatment efficiency.
\end{abstract}

It was found that MTBE treatment was more sensitive to up-set than gasoline hydrocarbon treatment. Events, such as excess iron accumulation, inhibited MTBE treatment, but not hydrocarbon treatment. Multiple regression analysis identified biomass accumulation and temperature as the most important variables controlling the efficiency of MTBE treatment. The influent concentration and loading of hydrocarbons, but not MTBE, also impacted MTBE treatment efficiency.

The results of this study suggest guidelines for improving MTBE treatment. Long cell retention times in the reactor are necessary for maintaining MTBE treatment. The onset of nitrification only occurs when long cell retention times have been reached and can be used as an indicator in fixed film reactors that conditions favorable to MTBE treatment exist. Conversely, if the reactor can not nitrify, it is unlikely to have stable MTBE treatment. Loading optimization based on biofilm or biomass measures, rather 
than based on reactor size, will give better process control. Finally, temperature should be controlled if possible. Our results suggest that a temperature in excess of $25^{\circ} \mathrm{C}$ may be optimal for MTBE treatment.

\section{Introduction}

Methyl tert-butyl ether (MTBE), a "fuel oxygenate" added to gasoline to promote efficient combustion, is now one of the most common groundwater pollutants in the United States (Squillace et al. 2001; Squillace et al. 1996; Pankow et al. 1997). MTBE is added intentionally to gasoline, but may also be found incidentally in other petroleum products, such as heating oil and diesel fuel, probably as a result of contamination during transport (Robbins et al. 2000). MTBE plumes have been reported in ground water contaminated with commercial jet fuel (Kang et al. 1999). Concern over the environmental and health impact of MTBE has escalated, an U. S. EPA drinking water advisory of 20 to $40 \mu \mathrm{g} / \mathrm{L}$ has been issued, and a treatment requirement between 5 and 35 $\mu \mathrm{g} / \mathrm{L}$ is required in many states (Lovett 1998; U. S. Environmental Protection Agency 1997; U. S. Environmental Protection Agency 1998).

MTBE contamination has complicated the remediation of gasoline contaminated sites. Water pumped from underground (as part of hydraulic containment or pump and treat actions) typically must be treated before discharge or reinjection. Many sites have historically used biological treatment for gasoline hydrocarbon removal and would like to apply the same technology to MTBE. However, the efficiency and reliability of MTBE biological treatment is not well documented. 
Several investigators have been able to maintain MTBE biodegrading treatment systems in the laboratory (Salanitro et al. 1994; Sun et al. 1996; Park and Cowan 1997; Fortin and Deshusses 1999a; Fortin and Deshusses 1999b; Acuna-Askar et al. 2000; Wilson et al. 2000; Stringfellow in press). In most cases, the reactors were difficult to start-up and were generally unstable, being easily subject to "up-set" or loss of MTBE treatment efficiency. In laboratory studies, the biological reactors are fed a synthetic mixture that is generally not representative of contaminated ground water, so the applicability of laboratory results to field applications is not clear. In particular, most laboratory reactors are fed influents containing MTBE as the sole carbon source, whereas in the field, biological treatment systems may be required to treat a complex influent containing minerals, solvents, and gasoline hydrocarbons as well as MTBE (Stringfellow et al. 2000).

Although there are several sites using biological treatment for the removal of MTBE from groundwater, there is little published information on the subject. Tang and Sun (1997) conducted a study of biological treatment of MTBE under field conditions using a complex waste stream. In this study, the use of a suspended growth reactor was compared to a fixed-film reactor for the treatment of tank-water spiked with MTBE by the researchers. Suspended growth reactors could be used for MTBE removal, but it was concluded that fixed-film reactors were more practical for field application. The study demonstrated that fluidized-bed reactors, containing granular activated carbon (GAC) as a bed material, had the potential to treat MTBE contaminated waste streams from a petroleum marketing terminal to low $\mu \mathrm{g} / \mathrm{L}$ effluent concentrations. However, MTBE degradation by the reactor was difficult to initiate, despite repeated inoculation with a 
laboratory mixed culture grown on MTBE as a sole carbon source. Additionally, the operational efficiency of the reactor was erratic. Emphasis was placed on the success of the reactor during a short stable operation period, and optimistic conclusions were drawn (Tang and Sun 1997). The reactor was not operated over an extended time, so it's long term stability is impossible to judge.

There are few other reports on MTBE biotreatment in the field. At a fuel transfer station in Northern California, full-scale fluidized-bed reactors containing GAC were installed to remove benzene, toluene, ethyl-benzene, and xylenes (BTEX) from gasoline contaminated ground water. The reactors began to remove MTBE after 200 days of operation (Mosteller et al. 1997, Stocking et al. in press). It was demonstrated that MTBE removal was the result of a combination of physical sorption and biodegradation, but that biological degradation could account for the majority of MTBE treatment in the system (Stringfellow 1998).

The exact mechanism of MTBE biodegradation is still not well defined. Organisms able to grow on MTBE as a sole carbon source have been identified in at least four laboratories (Salanitro et al. 1994, Mo et al. 1997, Hanson et al. 1999, Stringfellow in press). More laboratories have identified organisms able to co-metabolize MTBE (Hardison et al. 1997; Steffan et al. 1997; Hyman et al. 1998; Garnier et al. 1999; Solano-Serena et al. 2000; Piveteau et al. 2000, Corcho et al. 2000, Stringfellow in press). Organisms that are able to grow on low molecular weight alkanes found in gasoline can frequently co-metabolize MTBE (Hyman et al. 1998, Hyman and O'Reilly 1999, Garnier et al. 2000, Hyman et al. 2000, Solano-Serena et al. 2000, Stringfellow in press). Laboratory studies suggest that MTBE biodegradation in the fluidized bed 
bioreactors used in this study is predominantly a co-metabolic process, linked to alkane degrading bacteria (Stringfellow in press).

The objective of this study was to examine the operational and environmental variables influencing MTBE biotreatment under "real-world" conditions. Fluidized bed reactors were installed at a fuel transfer station and used to treat ground water contaminated with MTBE and gasoline hydrocarbons. A complete set of chemical and operational data was collected during this study and a statistical approach was used to determine what variables were influencing MTBE treatment efficiency in the reactor. The results presented here show that variations in MTBE treatment efficiency can be explained, and that application of fundamental biological treatment principles should increase MTBE treatment efficiency.

\section{Materials \& Methods}

\section{Chemical analysis}

Influent and effluent water samples from the reactor were collected twice per week and sent to a contract laboratory for analysis (Alpha Analytical, Reno, NV). Volatile organic compounds (including benzene, toluene, ethyl-benzene, xylenes, and MTBE) were measured by EPA Method 8260B. Extractable and purgable total petroleum hydrocarbons (TPH) were measured by EPA Method 8015B. TPH was calibrated to a gasoline standard. Total and ferrous iron was analyzed by the same laboratory according to EPA Method 200.7 and SM 3500 FE D. Chemical oxygen demand (COD), alkalinity, total suspended solids (TSS), ammonia-nitrogen and phosphate were measured using EPA approved methods. 
Biofilm on the GAC bed material was measured using a protein assay at Lawrence Berkeley National Laboratory. For biofilm analysis, one tenth of a gram of GAC (wet weight) was placed in a $2.5 \mathrm{~mL}$ centrifuge tube, $200 \mu \mathrm{L}$ of deionized water was added to each test tube, followed by $1.0 \mathrm{~mL}$ of Modified Lowery Protein Assay Reagent (Pierce, Rockford, IL) and, after 10 minutes, $100 \mu \mathrm{L}$ of diluted (1:1) FolinCiocalteu Reagent. The reaction was allowed to go to completion $(30 \mathrm{~min})$ and the absorbance of each sample was measured at $750 \mathrm{~nm}$ versus the blank sample. Results were quantitated using bovine serum albumin and expressed as $\mu$ g protein per gram dry weight GAC.

Iron content of the bed material was determined by acid extraction and colorometric determination. One half gram of oven dried GAC was added to $50 \mathrm{~mL}$ polypropylene centrifuge tube and extracted overnight using $10 \mathrm{~mL}$ of $1.0 \mathrm{~N} \mathrm{HCl}$. Five $\mathrm{mL}$ of the acid extract was placed in a 14-mL polypropylene test tube and adjusted to between $\mathrm{pH} 2.5$ and 5 using $700 \mu \mathrm{L}$ of $10 \% \mathrm{NH}_{4} \mathrm{OH}$ solution. The pH-adjusted solution was diluted appropriately and the total iron was measured colorometrically using the FerroVer Total Iron method (HACH Co., Loveland, CO). The accuracy of the colormetric method was confirmed by comparison to total iron analysis by atomic absorption spectroscopy (data not shown).

\section{Field measurements}

Dissolved oxygen, temperature, and $\mathrm{pH}$ were measured at the top of the reactor, near the effluent outlet of the reactor. Influent flow, reactor flow, oxygen flow, and reactor inlet pressure were measured at appropriate locations in the reactor using in-line gauges. Fluid bed height was measured from the top of the reactor using a weighted 
measuring line. Reactor fluidized bed volume (FBV) was calculated from fluid bed height measurements.

Influent ammonia-nitrogen and phosphate concentrations were calculated from measuring the volume of a known nutrient solution pumped into the reactor daily. Effluent ammonia-nitrogen and phosphate concentrations were measured using field kits (HACH Co., Loveland, CO). Effluent nutrient concentrations were monitored to maintain a minimum effluent concentration only and measurements above the maximum detection limit for the analysis were recorded as the maximum value. It was established that the reactor was not phosphate or nitrogen limited during this study.

\section{Site description:}

The field site was a fuel transfer station located in southern California. For the period included in this study, the maximum mean daily air temperature was $23.8^{\circ} \mathrm{C}$ and the minimum mean daily air temperature was $10.6^{\circ} \mathrm{C}$ (National Climatic Data Center 2000). The station is associated with a thoroughly characterized contaminant plume located in the shallow ground water table. The plume consists of gasoline hydrocarbons in mixture with MTBE. Contaminated ground water is collected from a network of capture wells and pumped to a physical treatment plant on site. For this study, part or all of the captured ground water was diverted to a 20,000-gallon equalization tank and then delivered to the biological treatment system. Influent samples were collected from the line between the equalization tank and the reactor.

\section{Fluidized bed reactor:}


The biological treatment system used in this study was a Model 30 fluidized bed reactor manufactured by USFilter, Envirex Products (Waukesha, WI). The reactor consisted of a 15 foot tall by 20 inch diameter tower, an influent flow control pump, a pump to fluidize the bed material with recycled reactor water, a biomass control system, and an oxygen contactor designed to maintain high oxygen concentrations without stripping volatile organic compounds (VOAs). The recycle flow was fixed at a rate of approximately $32 \mathrm{gpm}$ to maintain fluidization of the bed material as per the manufacturer's specifications. The oxygen delivery was on a feedback control to maintain an effluent concentration of $2.5 \mathrm{mg} / \mathrm{L}$. For most of the study period, the influent flow to the fluidized bed reactor was set at four gallons per minute (gpm) and was limited to that rate by available ground water flow. The temperature of the reactor was dependent on the ambient air temperature, influent water temperature and flow, and heating that occurs from compressed oxygen injection and recycle flow. In this study there was no attempt to control reactor temperature, except to avoid over heating during periods when influent flow was halted.

The tower was loaded with a solid bed material, in this case GAC, upon which bacteria are grown as a biofilm. As the biofilm grows on the GAC, the GAC becomes less dense, the bed material becomes more fluidized, and the bed height rises. Consequently, an increase in bed height is a measure of an increase in reactor biomass. The reactor is designed to control bed growth at 11 feet. When the bed height rises to the 11-foot control point, the biomass control system can be activated. The biomass control system draws biofilm coated GAC from the top of the bed through a pump that shears excess biomass from the GAC. The sheared biomass is buoyant and is discharged from 
the reactor and the cleaned GAC is retained in the reactor. In this study the bed only exhibited limited growth and the biomass control system was not activated.

\section{Calculations}

Loading rate is determined by calculating total daily loads $(\mathrm{mg} / \mathrm{L}$ influent concentration times daily flow in liters) and dividing by either the reactor volume or the total protein in the reactor. Removal rate (rate) is calculated from the mg of each constituent removed per day (influent $\mathrm{mg} / \mathrm{L}$ minus effluent $\mathrm{mg} / \mathrm{L}$, times flow) divided by the reactor volume. Volumetric loading and rate are expressed as mg of compound per liter reactor volume per day. Protein loading is expressed as mg of compound per mg of protein per day. The reactor volume was calculated based on the bed control point (682 L) rather than the fluidized bed volume (FBV) as calculated from bed height measurements. Statistical analyses conducted with loading and rate calculated as a function of FBV were not different from those calculated by reactor volume. For loading based on protein, the protein concentration of the GAC was multiplied by the total GAC originally added to the reactor to estimate total protein in the reactor.

\section{Statistical analysis}

Data from the first 76 days of the first field trial and all the data from the second and third field trials were pooled and used for the statistical analysis. Descriptive statistics and correlation tables were calculated using functions available in Excel (Microsoft Corp., Seattle, WA). A sub-set of the pooled data was used for multiple regression analysis (see results section for explanation). Multiple regression analysis was conducted using Essential Regression 2.218 (Steppan et al. 1998). Correlations were evaluated for significance at the $\alpha=0.05$ level using a t-test as described by Dowdy and 
Wearden (1983). A significant correlation does not prove, or even suggest, cause and effect. All variables that were tested for correlation were plotted against MTBE treatment efficiency to determine if the correlation analysis may have missed non-linear relationships. All non-linear relationships observed were identified at the significance level tested (e.g. Figure 9). Variables correlating with MTBE treatment efficiency were further evaluated by plotting and linear and non-linear curve fitting. In all cases, except as shown in Figures 9 and 13, linear regression was used to describe the relationship between variables.

\section{Results and Discussion}

\section{Field trial description}

Three field trials were conducted. The first trial (FT1) was conducted from March 3 to August 20, 1999 (Figure 1). The second trial (FT2) was conducted between October 26, 1999 and March 3, 2000 (Figure 2) and the third trial (FT3) was conducted April 5 and June 10, 2000 (Figure 3). In FT1, the reactor was loaded with $166 \mathrm{~kg}$ of Weststates coconut GAC. For FT2, the reactor was charged with $170 \mathrm{~kg}$ of Calgon coconut GAC. For FT3, the carbon from the second trial (FT2) was left in the reactor and used again.

The biological treatment system used in this study received ground water that contained gasoline hydrocarbons, ferrous iron, and MTBE (Table 1). The concentration and loading of many of the ground water constituents were correlated (Table 2). Notably, the variables relating to BTEX compounds and TPH measurements were closely correlated and MTBE and benzene were correlated. Benzene was not significantly correlated with the other BTEX compounds except ethyl-benzene (Table 2). 
The high correlation between influent benzene and MTBE can be explained by considering the relative solubility of the different components. Benzene, being the most soluble BTEX compound, behaves similarly to the soluble compound MTBE. These results suggest that within the hydrocarbon plume, relationships between components will be different from that observed at the limits of the plume, where it has been shown that there was a poor correlation between benzene and MTBE concentrations (Landmeyer et al. 1998). There was also correlation between some plant operational parameters and gasoline compound influent concentrations and loading. For example, toluene load is correlated with inlet pressure (Table 2). The correlation between independent variables is important in that it confounds simple interpretation of the data.

MTBE and o-xylene treatment efficiency (expressed as percent removed) over time for FT1 is presented in Figure 1. The reactor exhibited a rapid breakthrough of MTBE (less than 10 days), as is characteristic of fluidized bed reactors containing GAC as their bed material. After breakthrough, an MTBE degrading bacterial population quickly colonized the reactor as evidenced by the onset of MTBE treatment. This result was unexpected, in that prior reports had indicated that MTBE degradation can be difficult to establish in fluid bed reactors (Tang and Sun 1997, Mosteller et al. 1997).

A greater than $90 \%$ MTBE removal efficiency was maintained for over 60 days. At approximately 80 days of operation, MTBE treatment declined dramatically and in the remaining days of FT1 MTBE treatment continued to deteriorate (Figure 1). During this same period BTEX removal efficiency remained at approximately 100\%. Data for $o$ xylene is shown in Figure 1. During the latter part of this trial there was an accumulation of iron in the reactor that eventually prevented bed fluidization. 
Although we can relate several factors to MTBE treatment efficiency (see below), for FT1, the decline in MTBE treatment that occurred in the latter part of the trial can be attributed an accumulation of iron on the GAC that prevented bed fluidization. On day 76, the iron content of the GAC was $21.9 \mathrm{mg} / \mathrm{g} \mathrm{GAC}$ and the reactor was still operating at a 95\% MTBE treatment efficiency. By day 145, the iron content of the reactor was 43.2 $\mathrm{mg} / \mathrm{g} \mathrm{GAC}$, the bed would no longer fluidize, and treatment efficiency was less than $25 \%$. It should be noted however, that even during the period where fluidization was lost due to iron accumulation, removal of gasoline hydrocarbons was still essentially $100 \%$ (Figure 1).

For FT2, the bed was emptied of the iron coated GAC, virgin GAC was added to the reactor, and forward flow was started again. Hydrogen peroxide was added to the influent to the Baker tank at a concentration of $1.0 \mathrm{mg} / \mathrm{L}$ to pre-oxidize the iron before it entered the reactor. Prior experience at other facilities had shown that pre-oxidation of the iron prevented iron accumulation in fluidized bed reactors. For this trial, we began to monitor iron content of the reactor routinely. The average ( \pm standard deviation) iron concentration of the GAC during this trial was $14.5 \pm 2.5 \mathrm{mg} / \mathrm{g}$ bed material $(\mathrm{n}=6)$. There was no evidence that iron concentration was increasing over time during this trial.

Again MTBE breakthrough occurred within 10 days, but in this trial MTBE treatment efficiency was poor and unstable, with little improvement over time (Figure 2). Hydrocarbon treatment remained at approximately 100\% for this trial (data included in Figures 5, 6, and 7). After approximately 140 days of operation, the facility was scheduled to conduct maintenance of the well field and flow to the reactor was shut 
down. During this well-maintenance period, the reactor was neither fluidized nor aerated.

In FT2, MTBE treatment was limited, so in FT3 hydrogen peroxide pretreatment was discontinued. In the third trial MTBE treatment improved. The reactor was started again after a one-month shutdown. FT3 was started using the same GAC that had been used in the prior trial period, therefor the GAC had some biofilm already established and it's MTBE sorptive capacity was depleted.

During FT3, MTBE removal was improved compared to FT2, with an MTBE removal efficiency of $77 \%$ for the entire trial. MTBE removal seemed to be consistent over time until the last part of the trial, where the last data point showed a mark drop in treatment efficiency (Figure 3). The trial ended at this time, so it is not clear if this was a temporary anomaly in treatment or the beginning of a serious plant up-set. The average iron content during FT3 was $18.1 \pm 3.4(\mathrm{n}=8)$. There was a trend toward iron accumulation during this trial (Figure 4). Hydrocarbon removal remained approximately $100 \%$ for this trial as well (data included in Figures 5, 6, and 7).

\section{Importance of iron accumulation}

The results of the three trials suggested a role for ferrous iron in the degradation of MTBE. Laboratory tests were conducted that showed that MTBE degradation was stimulated under conditions favorable to "iron-bacteria," a poorly defined class of bacteria often found in wastewater treatment plants (Eaton et al. 1995). However, there is little evidence that ferrous iron limits or controls MTBE biodegradation directly. Rather, it is more likely that ferrous iron acts as a flocculent to retain biomass in the treatment system. Ferrous iron is commonly added to biological treatment plants to 
promote sludge settling (Tochobanoglous and Burton 1991). However when iron accumulates to excess levels, somewhere above $20 \mathrm{mg} / \mathrm{g}$, the accumulation of iron results in the loss of fluidization. Without fluidization, which provides mixing and contact, MTBE treatment is severely impaired. The sensitivity of the MTBE treatment process is apparent when MTBE removal is compared to hydrocarbon removal.

\section{MTBE treatment compared to hydrocarbon treatment}

Data from the three trials was compiled and examined to evaluate the ability of the fluidized bed bioreactor to treat gasoline hydrocarbons in comparison to MTBE. Benzene, toluene, ethyl-benzene, and o-, m- and p-xylenes (BTEX) were treated to nondetect levels $(<1 \mu \mathrm{g} / \mathrm{L})$ during most of the trial period (Table 1). Specific removal rates as a function of specific loading rates for selected compounds are shown in Figures 5, 6, 7 and 8. The reactor was very efficient at removing BTEX. Results shown in Figures 5 and 6 for o-xylene and benzene respectively are typical for the other BTEX compounds as well. The reactor was capable of removing total, purgable, and extractable TPH (Table 1). The relationship between loading and removal for purgable TPH is shown in Figure 7. There is no evidence that the treatment capacity of the reactor has been reached for any gasoline hydrocarbon and, therefor, hydrocarbon removal is a linear function of hydrocarbon loading rate.

It is apparent from our results that MTBE biodegradation is not following the classic pattern observed for the biodegradation of gasoline hydrocarbons. The relationship between MTBE loading and removal (Figure 8) is obviously of a different type from that of the hydrocarbons (Figures 5, 6, and 7). Loading and MTBE removal are more poorly related $\left(\mathrm{r}^{2}=0.771, \mathrm{n}=61\right)$ in comparison to the relationship observed 
with the gasoline hydrocarbons (e.g. purgable TPH, $\mathrm{r}^{2}=0.985, \mathrm{n}=50$ ) and it is apparent that variables other than MTBE loading are effecting treatment efficiency.

The complexity of MTBE treatment is also reflected in the variation that was experienced in the start-up of the field reactors. In the first trial and third trials, MTBE biotreatment initiated rapidly and reached a pseudo-steady state within ten or twenty days (Figures 1 and 3). In the second trial, MTBE treatment did not initiate rapidly and there instead appeared to be a long trend toward improved treatment (Figure 2). To meet the challenge of using biological treatment for remediating MTBE contaminated ground water it is imperative that the variation in treatment be explained and that this explanation allows us to propose approaches to improve the reliability of MTBE biotreatment.

\section{Independent and dependent variable assignments}

Data from the three trials were compiled and analyzed with the objective of identifying root factors controlling MTBE treatment efficiency. The data from the first 76 days of FT1 and all the data from FT2 and FT3 are considered in the analysis given below. Table 1 presents the summary statistics for all the variables considered in the statistical evaluation of MTBE treatment at this site. There were 89 variables included in this analysis, of which 39 were classified as dependent variables and 50 were considered independent variables (Table 1). Both the dependent and independent variables with an $\mathrm{n} \geq 10$ were tested for correlation to MTBE treatment efficiency (expressed as $\%$ MTBE removal). Significant correlations were found with 19 independent variables and 19 dependent variables (Table 3). 


\section{Correlation of MTBE treatment with independent variables}

Nineteen independent variables were significantly correlated with MTBE treatment (Table 3). Five operational variables (temperature, inlet pressure, fluid bed volume (FBV), protein concentration, and total protein) and fourteen influent and loading variables were significantly correlated with MTBE treatment efficiency. Variables with sufficient degrees of freedom were further evaluated using multiple regression analysis. As multiple regression can take into account correlation among independent variables, that method was applied where possible (Table 4).

Some parameters were not measured sufficiently often to include in the multiple regression analysis but still merit some discussion here. Independent variables that had a positive correlation with treatment efficiency include the protein content of the reactor and the protein content of the GAC (Figure 9), from which the reactor total protein is calculated. Treatment was negatively correlated with the independent variables of purgable TPH, extractable TPH, and toluene loading per gram protein. Treatment was not significantly correlated with MTBE loading per gram protein.

MTBE treatment as a function of purgable TPH and toluene loading on a protein basis is shown in Figures 10 and 11, respectively. These results suggest that treatment appears to be responding to hydrocarbon loading rather than MTBE loading, and treatment is better when the hydrocarbon/protein ratio is lower. This result is consistent with the laboratory results that suggested that MTBE degradation was the result of cometabolism in this reactor (Stringfellow 1998, Stringfellow in press). In a co-metabolic process, it is necessary to keep the primary substrate at a low concentration to stimulate degradation of the secondary substrate. However the correlation with total reactor 
protein and biofilm formation is also consistent with the mechanism of efficient cell retention that allows the development of a slow-growing MTBE degrading population. In either case it becomes apparent that the key variable is biomass retention in the reactor, either to allow the build-up of sufficient biomass to keep co-substrate concentrations low or to retain slow growing bacteria that will washout of inefficient systems. This conclusion is consistent with observations made for laboratory reactors, where MTBE treatment was dependent on the ability of the laboratory reactor to maintain a long sludge age (Wilson et al. 2000).

The correlation analysis also identified the other measurement of reactor biomass, FBV, as a significant independent variable. However, FBV is a somewhat crude measure of biomass and the degree of correlation among independent variables (Table 2) could obscure the relationship between MTBE treatment and any one variable. If the conclusions from the correlation analysis are correct, that biomass retention (and therefor accumulation) in the reactor is the key to maintaining good MTBE treatment, then the multiple regression analysis should identify a relationship between FBV and treatment efficiency.

\section{Multiple regression analysis}

The interactions between independent variables and between the independent variables and the dependent variable (\% MTBE removal) were examined using multiple regression analysis. Only a subset of data reported in Table 1 had sufficient degrees of freedom to be considered for multiple regression analysis (Table 4). Only complete data sets were included, so even though there were 62 available measurements for MTBE treatment efficiency, only 44 of those values had complete data sets. The summary 
statistics for the subset of data included in the linear multiple regression analysis are given in Table 4. The multiple regression analysis identified four significant independent variables out of the 25 variables tested (Table 5).

The variables temperature, fluid bed volume, influent purgable TPH concentration, and o-xylene load account for approximately $70 \%$ of the variation in MTBE treatment efficiency that was observed during these trials (Table 5a). The significance of this relationship is high and the auto-correlation of the variables is low (Table 5a,b). The coefficients for each variable are given in Table 5c. Increases in temperature, bed volume, and o-xylene load had a positive effect on MTBE treatment. An increase in purgable influent TPH concentration had a negative effect on MTBE treatment.

The results of this analysis are consistent with the correlation analysis, in that they also suggest that bacterial accumulation (increase in bed volume) in the reactor is important. Temperature, influent purgable TPH, and o-xylene loading are also identified as important variables. As temperature has a strong influence on bacteria growth rates, small changes in temperatures could be having a significant effect on the ability of the reactor to retain biomass. The identification of influent purgable TPH as an important variable is somewhat unexpected until one takes into account the fact that, although the fluid bed reactor behaves in a manner very similar to a complete mix reactor, it still retains some characteristics of a plug flow system. Plug flow systems respond to concentration variables as well as loading. If the alkane fraction of gasoline is the major co-metabolic substrate driving MTBE degradation, as has been proposed (Stringfellow in press), then it makes sense that the reactor should be sensitive to purgable TPH 
concentration, which measures the light alkane hydrocarbons shown to be the best substrates for MTBE co-metabolism. The positive influence of o-xylene load is minor, but significant. It is not certain from this data, because of the correlation among the aromatic hydrocarbons, whether o-xylene loading itself is important, or if it is actually another gasoline hydrocarbon that is having an impact. It is also not clear why this relationship is positive. Further work in this area is needed.

\section{Correlation with dependent variables}

Nineteen dependent variables correlated with \% MTBE removal (Table 3). The relationship between MTBE removal efficiency and treatment parameters such as effluent MTBE concentration and MTBE removal rate is obvious, but the negative correlation between MTBE removal and effluent $\mathrm{pH}$ requires some explanation (Figure 12). In these reactors, the effluent $\mathrm{pH}$ decreases as a result of the on-set of nitrification. The negative correlation between MTBE removal and $\mathrm{pH}$ indicates that the best MTBE removal occurs when the reactor is also nitrifying. This is consistent with observations made in the laboratory (Salanitro et al. 1994, Stringfellow unpublished data).

The correlation between nitrification and MTBE removal is consistent with the conclusion that MTBE removal is a function of biomass retention in the reactor. Nitrifying microorganisms are notoriously difficult to grow and retain in biological treatment systems (Grady and Lim 1980, Tochobanoglous and Burton 1991). If one examines the relationship between fluid bed volume and the decrease in $\mathrm{pH}$ (Figure 13) we can see that the decline in $\mathrm{pH}$ is associated with an increase in bed volume, an indication of biomass growth or accumulation in the reactor. 


\section{Development of guidelines for operation of MTBE treatment processes}

From this study, we can assemble a number of guidelines that, combined, should improve the operation of fluid bed reactors for the treatment of MTBE contaminated ground water. The concentration of iron on the bed material should be monitored. A small amount of iron accumulation appears beneficial and can contribute to the retention of biomass in the fluid bed reactor. If iron accumulates above a critical level (above 20 $\mathrm{mg} / \mathrm{g}$ for this reactor), fluidization is effected and MTBE removal is the first activity to be lost. Iron can be allowed to accumulate and then, when MTBE treatment is established, further accumulation can be prevented by the pre-oxidation of the iron with hydrogen peroxide or other means.

The occurrence of MTBE biodegradation is closely correlated with the onset of nitrification. This relationship has been observed in laboratory reactors, and it was first hypothesized that nitrifying bacteria may be responsible for MTBE degradation (Salanitro et al. 1994). There is now a significant body of evidence that nitrifying bacteria do not co-metabolize MTBE and are not responsible for MTBE removal in operating treatment systems (Sun et al. 1996, Hyman and O'Reilly 1999). Rather our study suggests that the conditions favorable for nitrification are also favorable for the onset of MTBE degradation. In activated sludge systems, the onset of nitrification requires an extended cell retention time (between four and eighty days), depending on conditions (Grady and Lim 1980). Nitrification only occurs in the reactor used in this study when the fluid bed volume exceeds 500 liters (Figure 13). Nitrification is sensitive to changes in temperature and easily inhibited by toxic compounds, such as BTEX (Grady and Lim 
1980; Tochobanoglous and Burton 1991). MTBE degradation was sensitive to temperature and influent purgable TPH concentrations (Table 5).

The results of this study suggest that nitrification should be monitored in field operational treatment systems. If the reactor can not nitrify, it is unlikely to degrade MTBE. In this study we did not monitor nitrification directly, but relied on $\mathrm{pH}$ measurement to indicate nitrification. We measured ammonia only to insure that there was sufficient ammonia in the effluent $(\geq 1 \mathrm{mg} / \mathrm{L})$ to maintain biological activity. It is recommended that ammonia, nitrite and nitrate be monitored in the influent and effluent of the reactor and used to guide reactor control operations.

The importance of cell retention in the reactor to MTBE treatment efficiency is evidenced by the relationship with biofilm development on the GAC (Figure 9) and the results of the multiple regression (Table 5). The reactor should be operated to maximize biomass retention. In fluid bed reactors there is little active control of the biomass accumulation in the reactor until the bed height reaches the control point of 11 feet (682 liters). At that point biomass can be reduced (wasted). In this study, there was only a poor accumulation of biomass, despite the significant hydrocarbon loading to the reactor, and the bed volume never exceeded 607 liters (Table 1). The reason biomass did not accumulate in this reactor is not certain.

We are currently testing two approaches to stimulating biofilm formation in fluid bed reactors. The first approach is to use carbon addition to stimulate the growth of MTBE degrading bacteria in the reactors. The second approach is to modify the design of the fluid beds to retain flocculating biomass as well as biofilm. Laboratory studies have shown the effectiveness of both approaches (Stringfellow in press), but the success 
of the laboratory has not yet been translated into the field. Further research in this area is continuing.

For MTBE treatment, loading should be optimized based on the biofilm or biomass measures; rater than just controlled based on reactor size. It would be possible to measure the protein content of the bed material in a wastewater laboratory using the methods described in this paper. Measurement of fluid bed volume is a crude measure of biomass, but may also serve as a control parameter.

Finally, temperature should be controlled if possible. Our results suggest that a temperature in excess of $25^{\circ} \mathrm{C}$ may be optimal for MTBE treatment. In this study the maximum measured temperature of the reactor reached $26.4^{\circ} \mathrm{C}$ without any negative effect on MTBE treatment (Table 1). The compressors and pumps of the fluid bed reactor generate significant heat. Increased insulation of the reactor vessel could significantly promote improved MTBE treatment.

\section{References}

Acuna-Askar, K., A. J. Englande, C. Hu, and G. Jin. 2000. Methyl tertiary-butyl ether (MTBE) biodegradation in batch and continuous upflow fixed biofilm reactors. Water Science and Technology 42, no. 5-6: 153-61.

Corcho, D., R. J. Watkinson, and D. N. Lerner. 2000. Cometabolic degradation of MTBE by a cyclohexane-oxidizing bacteria. In Bioremediation and Phytoremediation of Chlorinated and Recalcitrant Compounds. Eds G. B. Wickramanayake, A. R. Gavaskar, B. C. Alleman, and V. S. Magar, p. 183-90. Columbus, OH: Battelle Press.

Dowdy, S., and S. Wearden. 1983. Statistics for Research. New York: John Wiley \& Sons.

Eaton, A. D., L. S. Clesceri, and A. E. Greenberg. 1995. Standard Methods of the Examination of Water and Wastewater. 19th ed. Washington, DC: American Public Health Association. 
Fortin, N. Y., and M. A. Deshusses. 1999a. Treatment of methyl tert-butyl ether vapors in biotrickling filters. 1. Reactor startup, steady state performance, and culture characteristics. Environmental Science \& Technology 33, no. 17: 2980-2986.

Fortin, N. Y., and M. A. Deshusses. 1999b. Treatment of methyl tert-butyl ether vapors in biotrickling filters. 2. Analysis of the rate-limiting step and behavior under transient conditions. Environmental Science \& Technology 33, no. 17: 2987-91.

Garnier, P. M., R. Auria, C. Augur, and S. Revah. 1999. Cometabolic degradation of methyl t-butyl ether by Pseudomonas aeruginosa grown on pentane. Applied Microbiology and Biotechnology 51: 498-503.

Garnier, P. M., R. Auria, C. Augur, and S. Revah. 2000. Cometabolic biodegradation of methyl tert-butyl ether by a soil consortium: effect of components present in gasoline. Journal Of General And Applied Microbiology 46, no. 2: 79-84.

Grady, C. P. L., and H. C. Lim. 1980. Biological Wastewater Treatment: Theory and Applications. New York, NY: Marcel Dekker Inc.

Hanson, J. R., C. E. Ackerman, and K. M. Scow. 1999. Biodegradation of methyl tertbutyl ether by a bacterial pure culture. Applied and Environmental Microbiology 65, no. 11: 4788-92.

Hardison, L. K., S. S. Curry, L. M. Ciuffetti, and M. R. Hyman. 1997. Metabolism of diethyl ether and cometabolism of methyl tert-butyl ether by a filamentous fungus, a Graphium sp. Applied and Environmental Microbiology 63, no. 8: 3059-67.

Hyman, M. R., P. Kwon, K. Williamson, and K. O'Reilly. 1998. Cometabolism of MTBE by alkane-utilizing microorganisms. In Natural Attenuation: Chlorinated and Recalcitrant Compounds. Eds. G. B. Wickramanayake, and R. E. Hinchee, p. 32126. Columbus, OH: Battelle Press.

Hyman, M., and K. O'Reilly. 1999. Physiological and enzymatic features of MTBEdegrading bacteria. in In-Situ Bioremediation of Petroleum Hydrocarbons and Other Organic Compounds. Eds. B. C. Alleman, and A. Leeson, p. 7-12. Columbus, OH: Battelle Press.

Hyman, M., C. Taylor, and K. O'Reilly. 2000. Cometabolic degradation of MTBE by isoalkane-utilizing bacteria from gasoline impacted soils. In Bioremediation and Phytoremediation of Chlorinated and Recalcitrant Compounds. Eds. G. B. Wickramanayake, A. R. Gavaskar, B. C. Alleman, and V. S. Magar, p. 149-56. Vol. C2-4. Columbus, OH: Battelle Press.

Kang, J. J, P. B. Harrison, M. F. Pisarik, and W. T. Frankenberger. 1999. Enhanced MTBE biodegradation treatability study under aerobic and anaerobic conditions. Presented at The 5th International Symposium on In-Situ and On-Site Bioremediation. April $19-22$, San Diego, CA. 
Landmeyer, J. E., F. H. Chapelle, P. M. Bradley, J. F. Pankow, C. D. Church, and P. G. Tratnyek. 1998. Fate of MTBE relative to benzene in a gasoline-contaminated aquifer (1993-98). Ground Water Monitoring and Remediation 18, no. 4: 93-102.

Lovett, R. A. 1998. Drinking water - California proposes tighter MTBE standard. Environmental Science \& Technology 32, no. 13: A304-A304.

Mo, K., C. O. Lora, A. E. Wanken, M. Javanmardian, X. Yang, and C. F. Kulpa. 1997. Biodegradation of methyl t-butyl ether by pure bacterial cultures. Applied Microbiology and Biotechnology 47, no. 1: 69-72.

Mosteller, D. C., K. F. Reardon, A. W. Bourquin, B. Desilets, D. Dumont, R. Hines, and S. Kilkenny. 1997. Biotreatment of an MTBE-contaminated ground water. American Chemical Society, Division of Environmental Chemistry Preprints of Extended Abstracts, p. 420 421. Vol. 37.

National Climatic Data Center. 2000. Washington, DC: National Oceanographic and Atmospheric Administration. http://www.ncdc.noaa.gov/.

Pankow, J. F., N. R. Thomson, R. L. Johnson, A. L. Baehr, and J. S. Zogorski. 1997. The urban atmosphere as a non-point source for the transport of MTBE and other volatile organic compounds (VOCs) to shallow groundwater. Environmental Science \& Technology 31, no. 10: 2821-28.

Park, K., and R. M. Cowan. 1997. Biodegradation of gasoline oxygenates. In In-Situ and On-Site Bioremediation: Volume 1. Eds. B. C. Alleman, and A. Leeson, p. 17. Vol. 4 (1). Columbus, OH: Battelle Press.

Piveteau, P., F. Fayolle, Y. Le Penru, and F. Monot. 2000. Biodegradation of MTBE by cometabolism in laboratory-scale fermentations. In Bioremediation and Phytoremediation of Chlorinated and Recalcitrant Compounds. Eds. G. B. Wickramanayake, A. R. Gavaskar, B. C. Alleman, and V. S. Magar, p. 141-48. Vol. C2-4. Columbus, OH: Battelle Press.

Robbins, G. A., B. J. Heneby, T. M. Cummins, C. R. Goad, and E. J. Gilbert. 2000. Occurrence of MTBE in heating oil and diesel fuel in Connecticut. Ground Water Monitoring and Remediation 20, no. 4: 82-86.

Salanitro, J. P., L. A. Diaz, M. P. Williams, and H. L. Wisniewski. 1994. Isolation of a bacterial culture that degrades methyl $t$-butyl ether. Applied and Environmental Microbiology 60, no. 7: 2593-96.

Solano-Serena, F., R. Marchal, S. Casaregola, C. Vasnier, J.-M. Lebeault, and J.-P. Vandecasteele. 2000. A Mycobacterium strain with extended capacities for degradation of gasoline hydrocarbons. Applied and Environmental Microbiology 66, no. 6: 2392-99.

Squillace, P. J., J. S. Zogorski, W. G. Wilber, and C. V. Price. 1996. Preliminary 
assessment of the occurrence and possible sources of MTBE in groundwater in the United States, 1993-1994. Environmental Science \& Technology 30, no. 5: 1721-30.

Squillace, P. J., M. J. Moran, W. W. Lapham, C. V. Price, R. M. Clawges, and J. S. Zogorski. 2001. Volatile organic compounds in untreated ambient groundwater of the United States, 1985 -1995. Environmental Science and Technology.

Steffan, R. J., K. McClay, S. Vainberg, C. W. Condee, and D. L. Zhang. 1997. Biodegradation of the gasoline oxygenates methyl tert-butyl ether, ethyl tert-butyl ether, and tert-amyl methyl ether by propane-oxidizing bacteria. Applied and Environmental Microbiology 63, no. 11: 4216-22.

Steffan, R. J., S. Vainberg, C. Condee, K. McClay, and P. Hatzinger. 2000. Biotreatment of MTBE with a new bacterial isolate. In Bioremediation and Phytoremediation of Chlorinated and Recalcitrant Compounds. Eds. G. B. Wickramanayake, A. R. Gavaskar, B. C. Alleman, and V. S. Magar, 165-74. Columbus, OH: Battelle Press.

Steppan, D., D. J. Werner and R. P. Yeater. 1998. Essential Regression 2. 218. http://www.geocities.com/SiliconVally/Network/1900/ERPref.html/.

Stocking, A. J., R. A. Deeb, A. E. Flores, W. T. Stringfellow, J. Talley, R. Brownell, and Kavanaugh M. C. in press. Bioremediation of MTBE: a practical perspective. Biodegradation.

Stringfellow, W. T. 1998. Biodegradation of methyl tert-butyl ether by microorganisms found in a groundwater treatment system. Abstracts of the 98th Annual Meeting of the American Society for Microbiology, Atlanta, GA, May 17 - 21.

Stringfellow, W. T. in press. Applying co-metabolic biological reactions for the ex-situ treatment of MTBE contaminated ground water. In Exploring the Environmental Issues of Mobile, Recalcitrant Compounds in Gasoline. Eds. A. Diaz, and D. Drogos. Washington, DC: American Chemical Society Press.

Stringfellow, W. T., R. D. Hines, D. K. Cockrum, and T. S. Kilkenny. 2000. Factors influencing biological treatment of MTBE in fixed film reactors. Bioremediation and Phytoremediation of Chlorinated and Recalcitrant Compounds. G. B. Wickramanayake, A. R. Gavaskar, B. C. Alleman, and V. S. Magar, p. 175-81. Columbus, OH: Battelle Press.

Sun, P. T., J. P. Salanitro, and W. T. Tang. 1996. Fate and biokinetics of methyl t-butyl ether in activated sludge systems and it's engineering significance. Fifty-first Purdue Industrial Waste Conference Proceedings, p. 507-24. Chelsea, MI: Ann Arbor Press Inc.

Tang, W. T., and P. T. Sun. 1997. Field Evaluation of Biological and Non-Biological Treatment Technologies to Remove MTBE/Oxygenates from Petroleum Product 
Terminal Wastewaters. Publication Number 4655. Washington, DC: American Petroleum Institute.

Tochobanoglous, G., and F. L. Burton. 1991. Wastewater Engineering: Treatment, Disposal, and Reuse. 3rd ed. Metcalf \& Eddy Inc. New York: McGraw-Hill Publishing Co.

U. S. Environmental Protection Agency. 1997. Drinking Water Advisory: Consumer Acceptability Advice and Health Effects Analysis on Methyl Tertiary-Butyl Ether (MtBE). EPA-822-F-97-009. www.epa.gov/OUST/MTBE/. Washington, D. C.: Office of Water, U. S. Environmental Protection Agency.

U. S. Environmental Protection Agency. 1998. MTBE Fact Sheet \#1: Overview. EPA 510-F-97-014. www.epa.gov/OUST/MTBE/. Washington, DC: Office of Solid Waste and Emergency Response U. S. Environmental Protection Agency.

Wilson, G. J., A. P. Richter, M. T. Suidan, and A. D. Venosa. 2000. Mineralization of MTBE with various primary substrates. In Bioremediation and Phytoremediation of Chlorinated and Recalcitrant Compounds. Eds G. B. Wickramanayake, A. R. Gavaskar, B. C. Alleman, and V. S. Magar. p. 191-196. Columbus, OH: Battelle Press. 


\section{Figure legends}

Figure 1: MTBE and o-xylene removal efficiency during the first trial conducted March 3, 1999 to August 20, 1999.

Figure 2: MTBE removal efficiency during the second trial conducted October 26, 1999 to March 3, 2000.

Figure 3: MTBE removal efficiency during third trial conducted April 5, 2000 to June $10,2000$.

Figure 4: Accumulation of iron on GAC bed material during the third field trial (FT3).

Figure 5: Removal of o-xylene as a function of o-xylene loading of pilot reactor

Figure 6: Removal of benzene as a function of benzene loading of pilot reactor

Figure 7: Removal of purgable TPH as a function of purgable TPH loading of pilot reactor

Figure 8: Removal of MTBE as a function of MTBE loading of pilot reactor.

Figure 9: Relationship between MTBE treatment efficiency and protein content of the bed material. Protein content is a measurement of biofilm formation of the granular activated carbon.

Figure 10. Relationship between purgable TPH loading by protein and MTBE treatment efficiency

Figure 11. Relationship between toluene loading by protein and MTBE treatment efficiency

Figure 12: Relationship between MTBE treatment efficiency and effluent $\mathrm{pH}$ during field 
trials.

Figure 13: Relationship between effluent $\mathrm{pH}$ and bed height.

\section{Biographies}

William T. Stringfellow is a research engineer at Lawrence Berkeley National Laboratory. He received his Master's Degree in Microbial Physiology from Virginia Tech and his Ph. D. in Environmental Sciences and Engineering from the University of North Carolina at Chapel Hill. Dr. Stringfellow has over 15 years experience investigating the biological treatment of hazardous and industrial wastes. Dr. Stringfellow's research investigates microbial processes in engineered systems and the manipulation of co-metabolic processes for the treatment of contaminated soil and water.

Robert D. Hines, Jr., Director of Systems Projects and Process Services, USFilter, Envirex Products, Waukesha, Wisconsin. Mr. Hines manages industrial projects and directs the systems engineering and project management functions at USFilter, Envirex Products. He is also responsible for operation of the pilot program, process start-ups, and performance testing. He has extensive hands-on experience with wastewater treatment systems including the installation, commissioning, and start-up, of a $5.3 \mathrm{mgd}$ Fluid Bed System at a refinery in Cincinnati, Ohio. He has been employed by USFilter, Envirex Products since 1990. Mr. Hines received a B. S. in Chemical Engineering from Michigan Technological University in 1984 and is a registered professional engineer in Wisconsin.

Dirk K. Cockrum is an Environmental Specialist with Kinder Morgan Energy Partners. He has a Maasters of Science in Hydrogeology from the University of Nevada at Reno.

Scott T. Kilkenny is currently Vice President of Kinder Morgan, Inc. Mr. Kilkenny served as Director of Environmental Remediation and was responsible for the development and evaluation of MTBE treatment technologies. He received his B. S. Engineering UCLA in 1989. 
Table 1: Summary statistics for data collected in treatment study

\begin{tabular}{|c|c|c|c|c|c|c|}
\hline Variables & Type & mean & std dev & $\min$ & $\max$ & $\mathbf{n}$ \\
\hline Influent Flow Rate (L/day) & I & 21,055 & 3,536 & 0.0 & 23,981 & 198 \\
\hline HRT (hour) & I & 0.8 & 0.3 & 0.7 & 3.0 & 197 \\
\hline Reactor Flow Rate (gpm) & I & 31.4 & 1.6 & 26.0 & 36.6 & 198 \\
\hline Oxygen Flow Rate (CF/min) & I & 0.4 & 0.2 & 0.0 & 1.4 & 197 \\
\hline eff D.O. $(\mathrm{mg} / \mathrm{L})$ & I & 2.6 & 0.9 & 1.9 & 10.0 & 198 \\
\hline eff Temperature (C) & I & 21.5 & 2.4 & 6.2 & 26.4 & 198 \\
\hline eff pH & D & 6.3 & 0.4 & 5.7 & 11.0 & 198 \\
\hline Reactor Inlet Pressure (psig) & $\mathbf{I}$ & 8.2 & 1.8 & 6.0 & 12.0 & 198 \\
\hline Fluidized Bed Volume (L) & I & 477 & 64.8 & 372 & 608 & 194 \\
\hline in $\mathrm{NH}_{4}-\mathrm{N}(\mathrm{mg} / \mathrm{L})$ & I & 11.6 & 9.5 & 0.0 & 54.2 & 151 \\
\hline $\mathrm{NH}_{4}$-N load (mg/L/day) & I & 378 & 247 & 108 & 1,731 & 139 \\
\hline in $\mathrm{PO}_{4}(\mathrm{mg} / \mathrm{L})$ & I & 7.3 & 5.9 & 0.0 & 34.0 & 151 \\
\hline $\mathrm{PO}_{4} \operatorname{load}(\mathrm{mg} / \mathrm{L} / \mathrm{day})$ & I & 235 & 154 & 68.0 & 1,087 & 138 \\
\hline in MTBE $(\mu \mathrm{g} / \mathrm{L})$ & $\mathbf{I}$ & 4,774 & 3,039 & 1,600 & 11,000 & 62 \\
\hline eff MTBE $(\mu \mathrm{g} / \mathrm{L})$ & D & 1,721 & 1,560 & 210 & 6,900 & 62 \\
\hline MTBE rate (mg/L rx/day) & D & 92.1 & 95.9 & -6.2 & 325.2 & 61 \\
\hline MTBE load (mg/L rx/day) & $\mathbf{I}$ & 144 & 92.1 & 15.2 & 387 & 62 \\
\hline MTBE removed (\%) & D & 54.0 & 33.2 & 0.0 & 97.9 & 62 \\
\hline in TPH-p (mg/L) & I & 14.3 & 7.0 & 3.3 & 33.0 & 51 \\
\hline eff ТРH-p (mg/L) & D & 0.9 & 0.9 & 0.0 & 4.9 & 50 \\
\hline ТPH-p rate (mg/L rx/day) & D & 399 & 224 & 91.7 & 1,039 & 50 \\
\hline TPH-p load (mg/L rx/day_ & $\mathbf{I}$ & 430 & 234 & 108 & 1,081 & 51 \\
\hline TPH-p removed $(\%)$ & D & 92.7 & 6.1 & 74.7 & 100 & 50 \\
\hline in TPH-e $(\mathrm{mg} / \mathrm{L})$ & I & 2.4 & 2.6 & 0.0 & 12.0 & 51 \\
\hline eff TPH-e (mg/L) & D & 0.4 & 0.2 & 0.0 & 0.9 & 51 \\
\hline TPH-e rate (mg/L rx/day) & D & 58.8 & 79.6 & -5.3 & 368 & 51 \\
\hline TPH-e load (mg/L rx/day) & $\mathbf{I}$ & 70.2 & 81.0 & 0.0 & 384 & 51 \\
\hline TPH-e removed (\%) & D & 61.4 & 50.4 & -194 & 100 & 48 \\
\hline in TPH-t $(\mathrm{mg} / \mathrm{L})$ & $\mathbf{I}$ & 14.7 & 7.2 & 3.3 & 33.0 & 51 \\
\hline eff TPH-t $(\mathrm{mg} / \mathrm{L})$ & D & 1.0 & 1.0 & 0.0 & 4.9 & 51 \\
\hline TPH-t removed (\%) & D & 92.1 & 6.4 & 73.9 & 100 & 51 \\
\hline in Benzene $(\mu \mathrm{g} / \mathrm{L})$ & I & 3,112 & 1,998 & 5.0 & 7,200 & 62 \\
\hline eff Benzene $(\mu \mathrm{g} / \mathrm{L})$ & D & 19.1 & 73.2 & 0.0 & 550 & 62 \\
\hline Benzene rate (mg/L rx/day) & D & 93.3 & 61.0 & 0.1 & 238 & 62 \\
\hline Benzene load (mg/L rx/day) & $\mathbf{I}$ & 94.0 & 61.0 & 0.2 & 238 & 62 \\
\hline Benzene removed $(\%)$ & D & 99.0 & 2.6 & 84.3 & 100 & 62 \\
\hline in Toluene $(\mu \mathrm{g} / \mathrm{L})$ & $\mathbf{I}$ & 1,124 & 880 & 18.0 & 3,900 & 62 \\
\hline eff Toluene $(\mu \mathrm{g} / \mathrm{L})$ & D & 12.9 & 57.8 & 0.0 & 430 & 62 \\
\hline Toluene rate (mg/L rx/day) & D & 33.9 & 28.3 & 0.6 & 128 & 62 \\
\hline Toluene load (mg/L rx/day) & $\mathbf{I}$ & 34.3 & 28.7 & 0.6 & 128 & 62 \\
\hline Toluene removed $(\%)$ & D & 99.0 & 2.7 & 83.5 & 100 & 62 \\
\hline in Ethyl-benzene $(\mu \mathrm{g} / \mathrm{L})$ & $\mathbf{I}$ & 170 & 172 & 0.0 & 940 & 60 \\
\hline eff Ethyl-benzene $(\mu \mathrm{g} / \mathrm{L})$ & D & 2.0 & 6.1 & 0.0 & 44.0 & 60 \\
\hline EB rate (mg/L rx/day) & D & 5.4 & 5.6 & 0.0 & 30.8 & 59 \\
\hline EB load (mg/L rx/day) & I & 5.4 & 5.7 & 0.0 & 30.8 & 60 \\
\hline Ethyl-benzene removed (\%) & D & 97.3 & 6.4 & 62.5 & 100 & 56 \\
\hline in m,p-Xylene ( $\mu \mathrm{g} / \mathrm{L})$ & I & 1,073 & 762 & 110 & 3,200 & 58 \\
\hline eff m,p-Xylene $(\mu \mathrm{g} / \mathrm{L})$ & D & 20.9 & 75.5 & 0.0 & 460 & 58 \\
\hline $\mathrm{m}, \mathrm{p}-\mathrm{X}$ rate $(\mathrm{mg} / \mathrm{L} \mathrm{rx} / \mathrm{day})$ & D & 31.8 & 23.8 & 3.5 & 105 & 58 \\
\hline m,p-X load (mg/L rx/day) & $\mathbf{I}$ & 32.4 & 24.3 & 3.8 & 105 & 58 \\
\hline m,p-Xylene removed (\%) & D & 98.3 & 4.3 & 72.9 & 100 & 58 \\
\hline in o-Xylene $(\mu \mathrm{g} / \mathrm{L})$ & $\mathbf{I}$ & 550 & 375 & 100 & 1,500 & 55 \\
\hline eff o-Xylene $(\mu \mathrm{g} / \mathrm{L})$ & D & 11.9 & 38.0 & 0.0 & 210 & 55 \\
\hline
\end{tabular}




\begin{tabular}{|c|c|c|c|c|c|c|}
\hline Variables & Type & mean & std dev & $\min$ & $\max$ & $\overline{\mathbf{n}}$ \\
\hline o-X rate (mg/L rx/day) & D & 16.2 & 11.6 & 3.3 & 49.1 & 55 \\
\hline o-X load (mg/L rx/day) & $\mathbf{I}$ & 16.6 & 11.7 & 3.3 & 49.1 & 55 \\
\hline o-Xylene removed $(\%)$ & D & 97.9 & 5.6 & 68.2 & 100 & 55 \\
\hline in COD $(\mathrm{mg} / \mathrm{L})$ & $\mathbf{I}$ & 77.1 & 29.9 & 32.0 & 180 & 30 \\
\hline eff COD $(\mathrm{mg} / \mathrm{L})$ & D & 36.5 & 13.8 & 13.0 & 63.0 & 30 \\
\hline COD rate $(\mathrm{mg} / \mathrm{L}$ rx/day $)$ & D & 1,234 & 906 & 229 & 4,376 & 30 \\
\hline COD load (mg/L rx/day) & $\mathbf{I}$ & 2,343 & 989 & 911 & 5,322 & 30 \\
\hline COD removed $(\%)$ & D & 49.4 & 17.6 & 20.7 & 85.5 & 30 \\
\hline in Total iron (mg/L) & $\mathbf{I}$ & 3.6 & 2.7 & 0.6 & 12.0 & 16 \\
\hline eff Total iron (mg/L) & D & 1.8 & 1.7 & 0.3 & 6.0 & 16 \\
\hline Total Fe rate (mg/L rx/day) & D & 59.2 & 90.6 & -16.4 & 358 & 16 \\
\hline Total Fe load (mg/L rx/day) & $\mathbf{I}$ & 102 & 86.1 & 18.7 & 384 & 16 \\
\hline Total Fe removed (\%) & D & 43.3 & 42.1 & -29.4 & 93.3 & 16 \\
\hline in Ferrous iron (mg/L) & $\mathbf{I}$ & 2.6 & 1.4 & 0.2 & 5.0 & 17 \\
\hline eff Ferrous iron $(\mathrm{mg} / \mathrm{L})$ & D & 0.2 & 0.3 & 0.1 & 1.1 & 17 \\
\hline Ferrous rate (mg/L rx/day) & D & 69.3 & 39.9 & 3.3 & 152 & 17 \\
\hline Ferrous load (mg/L rx/day) & $\mathbf{I}$ & 75.6 & 44.8 & 6.6 & 164 & 17 \\
\hline Ferrous removed $(\%)$ & D & 89.7 & 12.0 & 50.0 & 99.0 & 17 \\
\hline Inf. Ferrous (\% of Total) & $\mathbf{I}$ & 81.5 & 31.8 & 17.6 & 124 & 16 \\
\hline Eff. Ferrous (\% of Total) & D & 18.7 & 19.8 & 1.9 & 61.1 & 16 \\
\hline in TSS (mg/L) & $\mathbf{I}$ & 15.8 & 0.5 & 15.0 & 16.0 & 4 \\
\hline eff TSS $(\mathrm{mg} / \mathrm{L})$ & D & 29.8 & 18.9 & 6.0 & 46.0 & 4 \\
\hline in Alkalinity (mg/L) & $\mathbf{I}$ & 506 & 57.6 & 440 & 546 & 3 \\
\hline eff Alkalinity (mg/L) & D & 552 & 21.6 & 528 & 570 & 3 \\
\hline Iron in GAC (mg/g GAC) & $\mathbf{I}$ & 16.9 & 3.6 & 12.3 & 21.9 & 15 \\
\hline Protein in GAC $(\mu \mathrm{g} / \mathrm{g}$ GAC $)$ & I & 2,508 & 1,030 & 1,108 & 4,197 & 13 \\
\hline Protein in reactor (mg total) & I & 416,328 & 170,950 & 183,928 & 696,702 & 13 \\
\hline MTBE protein load (mg/mg/day) & I & 0.18 & 0.08 & 0.07 & 0.30 & 10 \\
\hline TPH-p protein load (mg/mg/day) & I & 0.62 & 0.43 & 0.16 & 1.57 & 10 \\
\hline TPH-e protein load (mg/mg/day) & I & 0.10 & 0.10 & 0.02 & 0.34 & 10 \\
\hline BNZ protein load (mg/mg/day) & $\mathbf{I}$ & 0.12 & 0.08 & 0.00 & 0.25 & 10 \\
\hline TOL protein load (mg/mg/day) & I & 0.05 & 0.04 & 0.01 & 0.13 & 10 \\
\hline EB protein load (mg/mg/day) & I & 0.01 & 0.01 & 0.00 & 0.02 & 9 \\
\hline m,p-X protein load (mg/mg/day) & I & 0.06 & 0.05 & 0.01 & 0.13 & 9 \\
\hline o-X protein load (mg/mg/day) & $\mathbf{I}$ & 0.05 & 0.04 & 0.01 & 0.11 & 8 \\
\hline COD protein load (mg/mg/day) & $\mathbf{I}$ & 3.62 & 1.85 & 1.10 & 5.66 & 5 \\
\hline
\end{tabular}

$\mathrm{I}=$ independent variable; $\mathrm{D}=$ dependent variable; in $=$ influent, eff $=$ effluent, $\mathrm{rx}=$ reactor, $\mathrm{HRT}=$

hydraulic retention time, FBV = fluid bed volume, D. O. = dissolved oxygen, TPH-p = purgable-TPH,

TPH-e $=$ extractable-TPH, TPH- $\mathrm{t}=$ total-TPH, BNZ $=$ benzene, $\mathrm{TOL}=$ toluene, $\mathrm{m}, \mathrm{p}-\mathrm{X}=\mathrm{m}, \mathrm{p}-\mathrm{xylene}, \mathrm{o}-\mathrm{X}$

$=$ o-xylene, $\mathrm{EB}=$ ethyl-benzene, $\mathrm{COD}=$ chemical oxygen demand, 


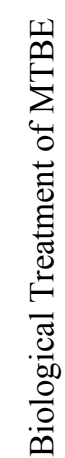

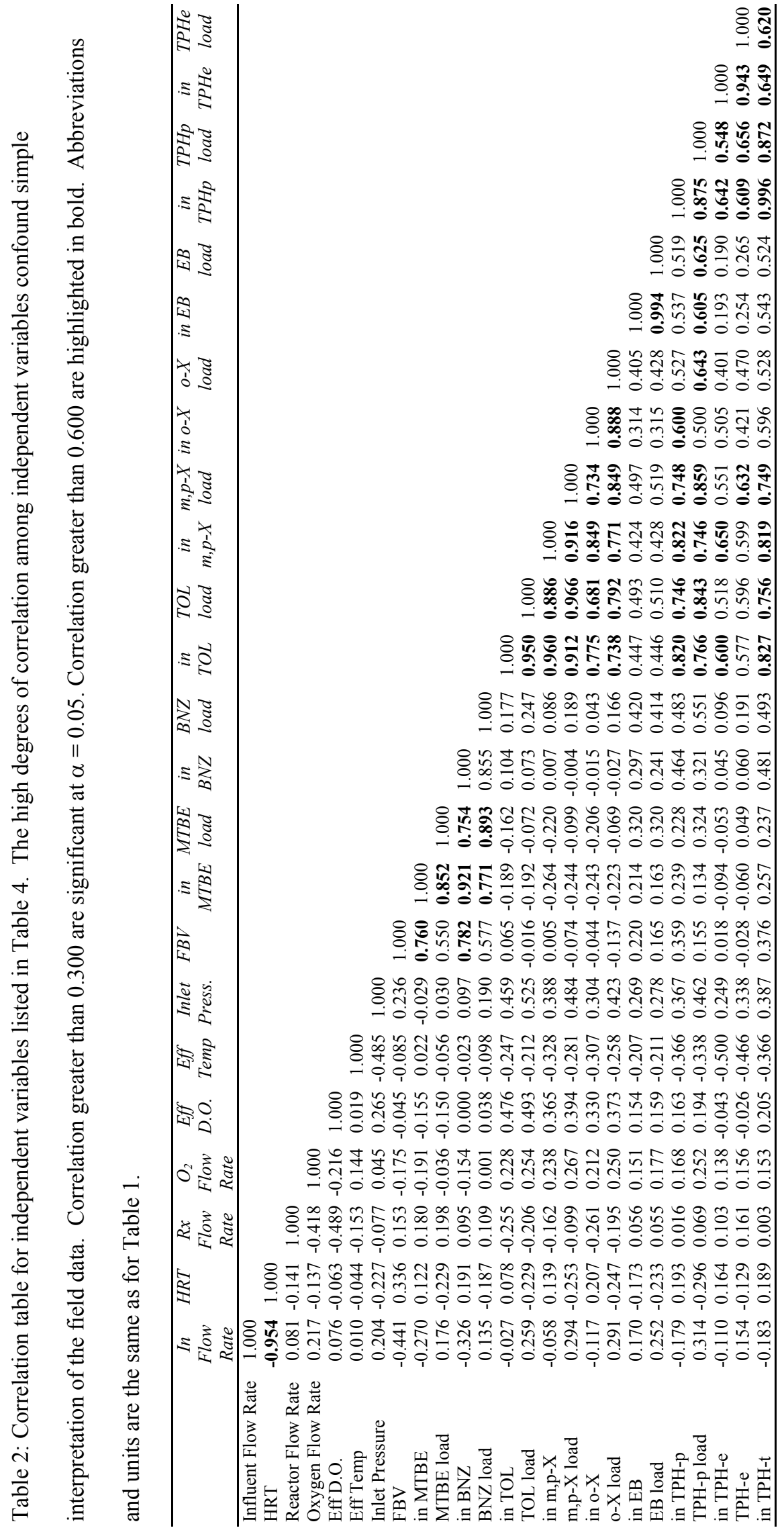


Table 3: Correlation between MTBE removal efficiency and all variables. Correlation highlighted in bold are significant at $\alpha=0.05$. Abbreviations are the same as for Table 1 .

\begin{tabular}{|c|c|c|c|}
\hline Variable & Type & $\begin{array}{c}\text { \% MTBE } \\
\text { removed } \\
\text { (r) }\end{array}$ & n \\
\hline MTBE removed (\%) & D & 1.000 & 62 \\
\hline Influent Flow Rate (L/day) & $\mathbf{I}$ & -0.044 & 62 \\
\hline HRT (hour) & $\mathbf{I}$ & -0.030 & 62 \\
\hline Reactor Flow Rate (gpm) & $\mathbf{I}$ & -0.022 & 62 \\
\hline Oxygen Flow Rate (CF/min) & I & 0.048 & 62 \\
\hline eff D.O. $(\mathrm{mg} / \mathrm{L})$ & $\mathbf{I}$ & -0.001 & 62 \\
\hline eff Temperature (C) & $\mathbf{I}$ & 0.535 & 62 \\
\hline eff $\mathrm{pH}$ & D & -0.704 & 62 \\
\hline Reactor Inlet Pressure (psig) & I & -0.364 & 62 \\
\hline Fluidized Bed Volume (L) & I & 0.511 & 61 \\
\hline in $\mathrm{NH}_{4}-\mathrm{N}(\mathrm{mg} / \mathrm{L})$ & $\mathbf{I}$ & -0.006 & 44 \\
\hline $\mathrm{NH}_{4}$-N load (mg/L/day) & I & -0.001 & 39 \\
\hline in $\mathrm{PO}_{4}(\mathrm{mg} / \mathrm{L})$ & I & -0.006 & 44 \\
\hline $\mathrm{PO}_{4}$ load $(\mathrm{mg} / \mathrm{L} / \mathrm{day})$ & I & -0.001 & 39 \\
\hline in $\operatorname{MTBE}(\mu \mathrm{g} / \mathrm{L})$ & $\mathbf{I}$ & 0.493 & 62 \\
\hline eff $\operatorname{MTBE}(\mu \mathrm{g} / \mathrm{L})$ & D & -0.695 & 62 \\
\hline MTBE rate (mg/L rx/day) & D & 0.759 & 61 \\
\hline MTBE load (mg/L rx/day) & $\mathbf{I}$ & 0.428 & 62 \\
\hline in TPH-p (mg/L) & $\mathbf{I}$ & -0.251 & 51 \\
\hline eff TPH-p $(\mathrm{mg} / \mathrm{L})$ & D & -0.478 & 50 \\
\hline TPH-p rate (mg/L rx/day) & D & -0.200 & 50 \\
\hline TPH-p load (mg/L rx/day_ & $\mathbf{I}$ & -0.265 & 51 \\
\hline TPH-p removed (\%) & D & 0.414 & 50 \\
\hline in TPH-e $(\mathrm{mg} / \mathrm{L})$ & $\mathbf{I}$ & -0.394 & 51 \\
\hline eff TPH-e (mg/L) & D & 0.376 & 51 \\
\hline TPH-e rate (mg/L rx/day) & D & -0.402 & 51 \\
\hline TPH-e load (mg/L rx/day) & $\mathbf{I}$ & -0.367 & 51 \\
\hline TPH-e removed (\%) & D & -0.551 & 48 \\
\hline in TPH-t $(\mathrm{mg} / \mathrm{L})$ & $\mathbf{I}$ & -0.231 & 51 \\
\hline eff TPH-t (mg/L) & D & -0.507 & 51 \\
\hline TPH-t removed (\%) & D & 0.440 & 51 \\
\hline in Benzene $(\mu \mathrm{g} / \mathrm{L})$ & $\mathbf{I}$ & 0.428 & 62 \\
\hline eff Benzene $(\mu \mathrm{g} / \mathrm{L})$ & D & -0.261 & 62 \\
\hline Benzene rate (mg/L rx/day) & D & 0.375 & 62 \\
\hline Benzene load (mg/L rx/day) & I & 0.365 & 62 \\
\hline Benzene removed (\%) & D & 0.234 & 62 \\
\hline in Toluene $(\mu \mathrm{g} / \mathrm{L})$ & $\mathbf{I}$ & -0.320 & 62 \\
\hline eff Toluene $(\mu \mathrm{g} / \mathrm{L})$ & D & -0.225 & 62 \\
\hline Toluene rate (mg/L rx/day) & D & -0.278 & 62 \\
\hline Toluene load (mg/L rx/day) & $\mathbf{I}$ & -0.288 & 62 \\
\hline Toluene removed $(\%)$ & D & 0.348 & 62 \\
\hline in Ethyl-benzene ( $\mu \mathrm{g} / \mathrm{L})$ & $\mathbf{I}$ & -0.096 & 60 \\
\hline eff Ethyl-benzene $(\mu \mathrm{g} / \mathrm{L})$ & D & -0.235 & 60 \\
\hline
\end{tabular}




\begin{tabular}{|c|c|c|c|}
\hline Variable & Type & $\begin{array}{c}\text { \% MTBE } \\
\text { removed } \\
(r)\end{array}$ & $\mathbf{n}$ \\
\hline EB rate (mg/L rx/day) & $\mathbf{D}$ & -0.126 & 59 \\
\hline EB load (mg/L rx/day) & $\mathbf{I}$ & -0.115 & 60 \\
\hline Ethyl-benzene removed (\%) & D & 0.231 & 56 \\
\hline in m,p-Xylene $(\mu \mathrm{g} / \mathrm{L})$ & $\mathbf{I}$ & -0.399 & 58 \\
\hline eff m,p-Xylene $(\mu \mathrm{g} / \mathrm{L})$ & D & -0.276 & 58 \\
\hline m,p-X rate (mg/L rx/day) & D & $-\mathbf{0 . 3 3 9}$ & 58 \\
\hline m,p-X load (mg/L rx/day) & $\mathbf{I}$ & -0.359 & 58 \\
\hline m,p-Xylene removed (\%) & $\mathbf{D}$ & $\mathbf{0 . 3 8 2}$ & 58 \\
\hline in o-Xylene $(\mu \mathrm{g} / \mathrm{L})$ & $\mathbf{I}$ & -0.268 & 55 \\
\hline eff 0 -Xylene $(\mu \mathrm{g} / \mathrm{L})$ & D & -0.293 & 55 \\
\hline $0-X$ rate (mg/L rx/day) & D & -0.194 & 55 \\
\hline o-X load (mg/L rx/day) & $\mathbf{I}$ & -0.222 & 55 \\
\hline o-Xylene removed (\%) & D & 0.360 & 55 \\
\hline in COD $(\mathrm{mg} / \mathrm{L})$ & $\mathbf{I}$ & 0.224 & 30 \\
\hline eff COD (mg/L) & $\mathbf{D}$ & 0.214 & 30 \\
\hline COD rate (mg/L rx/day) & $\mathbf{D}$ & 0.063 & 30 \\
\hline COD load (mg/L rx/day) & $\mathbf{I}$ & 0.085 & 30 \\
\hline COD removed $(\%)$ & $\mathbf{D}$ & -0.017 & 30 \\
\hline in Total iron (mg/L) & $\mathbf{I}$ & -0.273 & 16 \\
\hline eff Total iron (mg/L) & D & 0.477 & 16 \\
\hline Total Fe rate (mg/L rx/day) & D & -0.549 & 16 \\
\hline Total Fe load (mg/L rx/day) & $\mathbf{I}$ & -0.531 & 16 \\
\hline Total Fe removed (\%) & D & -0.488 & 16 \\
\hline in Ferrous iron (mg/L) & $\mathbf{I}$ & -0.297 & 17 \\
\hline eff Ferrous iron (mg/L) & D & -0.380 & 17 \\
\hline Ferrous rate (mg/L rx/day) & D & -0.556 & 17 \\
\hline Ferrous load (mg/L rx/day) & $\mathbf{I}$ & -0.580 & 17 \\
\hline Ferrous removed $(\%)$ & D & -0.138 & 17 \\
\hline Inf. Ferrous (\% of Total) & $\mathbf{I}$ & -0.246 & 16 \\
\hline Eff. Ferrous (\% of Total) & D & -0.146 & 16 \\
\hline Iron in GAC (mg/g GAC) & $\mathbf{I}$ & 0.354 & 12 \\
\hline Protein in GAC $(\mu \mathrm{g} / \mathrm{g}$ GAC) & $\mathbf{I}$ & 0.643 & 10 \\
\hline Protein in reactor (mg total) & $\mathbf{I}$ & 0.643 & 10 \\
\hline MTBE protein load (mg/mg/day) & $\mathbf{I}$ & -0.542 & 10 \\
\hline ТPH-p protein load (mg/mg/day) & $\mathbf{I}$ & -0.814 & 10 \\
\hline TPH-e protein load (mg/mg/day) & $\mathbf{I}$ & -0.807 & 10 \\
\hline BNZ protein load (mg/mg/day) & $\mathbf{I}$ & -0.592 & 10 \\
\hline TOL protein load (mg/mg/day) & $\mathbf{I}$ & -0.711 & 10 \\
\hline
\end{tabular}


Table 4: Table of variables used in correlation table (Table 2) multiple regression analysis (Table 5). Abbreviations are listed in Table 1.

\begin{tabular}{lrrrrr}
\hline & mean & sd & min & max & $\mathbf{n}=$ \\
\hline \% MTBE removed & 43.3 & 31.2 & 0.00 & 97.9 & 44 \\
Influent Flow Rate & 20600 & 4316 & 5450 & 23436 & 44 \\
HRT & 0.88 & 0.45 & 0.70 & 3.00 & 44 \\
Reactor Flow Rate & 31.2 & 1.85 & 26.0 & 33.9 & 44 \\
Oxygen Flow Rate & 0.50 & 0.28 & 0.10 & 1.40 & 44 \\
Eff D.O. & 2.75 & 1.32 & 1.90 & 10.0 & 44 \\
Eff Temp & 21.4 & 2.00 & 17.2 & 25.8 & 44 \\
Inlet Pressure & 8.67 & 1.63 & 6.00 & 12.0 & 44 \\
FBV & 469 & 63.8 & 372 & 608 & 44 \\
in MTBE & 3893 & 2455 & 1600 & 10000 & 44 \\
MTBE load & 113 & 66.5 & 15.2 & 336 & 44 \\
in BNZ & 2719 & 1784 & 20.0 & 7200 & 44 \\
BNZ load & 78.5 & 48.9 & 0.64 & 238 & 44 \\
in TOL & 1271 & 973 & 18.0 & 3900 & 44 \\
TOL load & 38.3 & 32.1 & 0.60 & 128 & 44 \\
in m,p-X & 1212 & 822 & 110 & 3200 & 44 \\
m,p-X load & 36.3 & 26.6 & 3.78 & 105 & 44 \\
in o-X & 598 & 391 & 100 & 1500 & 44 \\
0-X load & 17.8 & 12.3 & 3.28 & 49.2 & 44 \\
in EB & 177 & 193 & 0.00 & 940 & 44 \\
EB load & 5.54 & 6.36 & 0.00 & 30.8 & 44 \\
in TPH-p & 14.8 & 7.32 & 3.30 & 33.0 & 44 \\
TPH-p load & 439 & 246 & 108 & 1081 & 44 \\
in TPH-e & 2.48 & 2.78 & 0.00 & 12.0 & 44 \\
TPH-e & 73.0 & 86.1 & 0.00 & 383 & 44 \\
in TPH-t & 15.1 & 7.52 & 3.30 & 33.0 & 44 \\
\hline & & & & &
\end{tabular}


Table 5: Results of multiple regression analysis. Abbreviations are given in Table 1.

a.

\begin{tabular}{lr}
\hline \multicolumn{1}{c}{ Summary } \\
\hline$|\mathbf{R}|$ & 0.850 \\
R2 & 0.722 \\
R2 adjusted & 0.694 \\
Standard Error & 17.23 \\
\# Points & 44 \\
PRESS & 14380 \\
R2 for Prediction & 0.655 \\
Durbin-Watson d & 1.711 \\
First Order & 0.109 \\
Autocorrelation & \\
Collinearity & 0.449 \\
Coefficient of Variation & 39.835 \\
\hline
\end{tabular}

b.

\begin{tabular}{lrrrrrr}
\hline \multicolumn{7}{c}{ ANOVA } \\
\hline \multicolumn{1}{c}{ Source } & \multicolumn{1}{c}{$S S$} & \multicolumn{1}{c}{$S S \%$} & $M S$ & $F$ & $F$ Signif & $d f$ \\
\hline Regression & 30143.3 & 72 & 7535.8 & 25.37 & $2.115 \mathrm{e}-10$ & 4 \\
Residual & 11583.3 & 28 & 297.01 & & & 39 \\
Total & 41726.6 & 100 & & & & 43 \\
\hline
\end{tabular}

c.

\begin{tabular}{|c|c|c|c|c|c|c|c|}
\hline \multicolumn{8}{|c|}{ \% MTBE removed $=b 0+b 1 * E f f$ Temp $+b 2 * F B V+b 3 *$ in TPH-p $+b 4 * o-X$ load } \\
\hline \multirow[b]{2}{*}{ intercept } & \multicolumn{2}{|c|}{$\mathrm{P}$ value } & $\begin{array}{l}\text { Std } \\
\text { Error }\end{array}$ & $-95 \%$ & \multicolumn{2}{|c|}{$95 \%$ t Stat } & VIF \\
\hline & -299.60 & $2.212 \mathrm{e}-09$ & 38.78 & -378.04 & -221.15 & -7.725 & \\
\hline Temperature & 8.949 & $1.856 \mathrm{e}-07$ & 1.416 & 6.086 & 11.81 & 6.321 & 1.163 \\
\hline FBV & 0.350 & $1.030 \mathrm{e}-08$ & 0.04842 & 0.252 & 0.448 & 7.232 & 1.383 \\
\hline In TPH-p & -1.698 & 0.00185 & 0.508 & -2.726 & -0.670 & -3.340 & 2.006 \\
\hline 0 -xylene load & 0.686 & 0.01739 & 0.276 & 0.127 & 1.244 & 2.484 & 1.675 \\
\hline
\end{tabular}


Figure 1: MTBE and o-xylene removal efficiency during first trial conducted March 3, 1999 to August 20, 1999

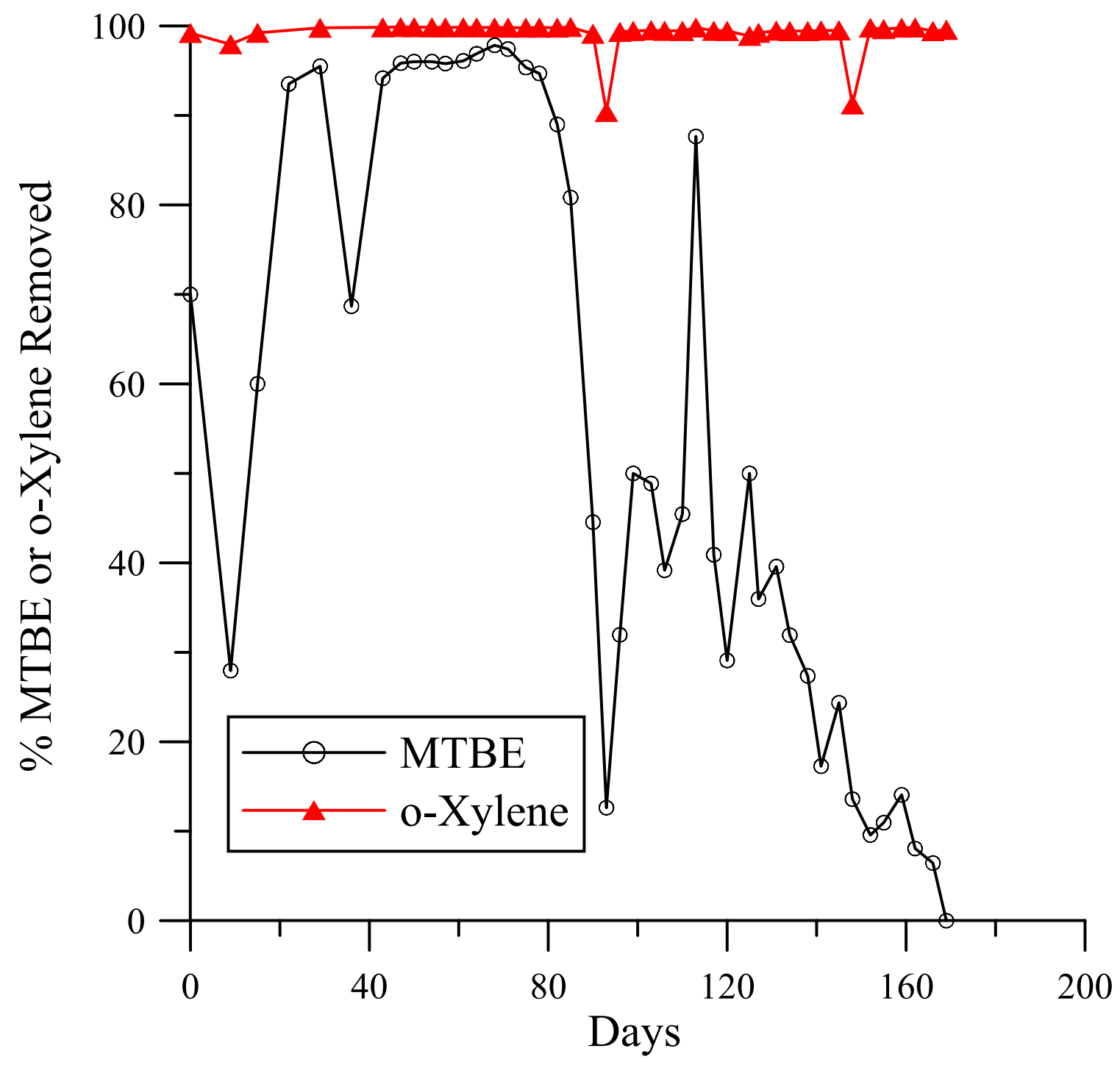


Figure 2: MTBE removal efficiency during second trial conducted October 26, 1999 to March 3, 2000

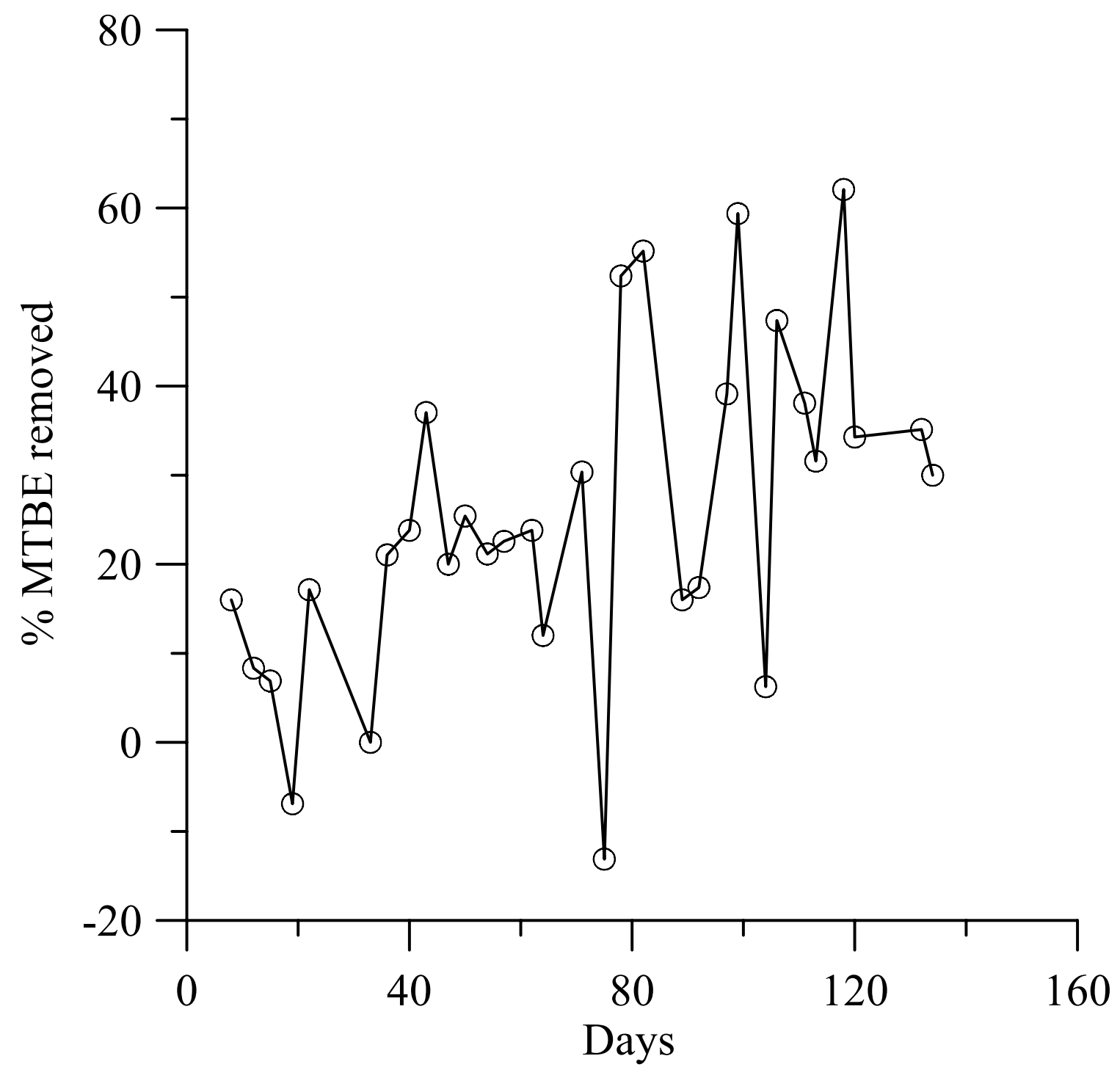


Figure 3: MTBE removal efficiency during third trial conducted April 5, 2000 to June 10, 2000

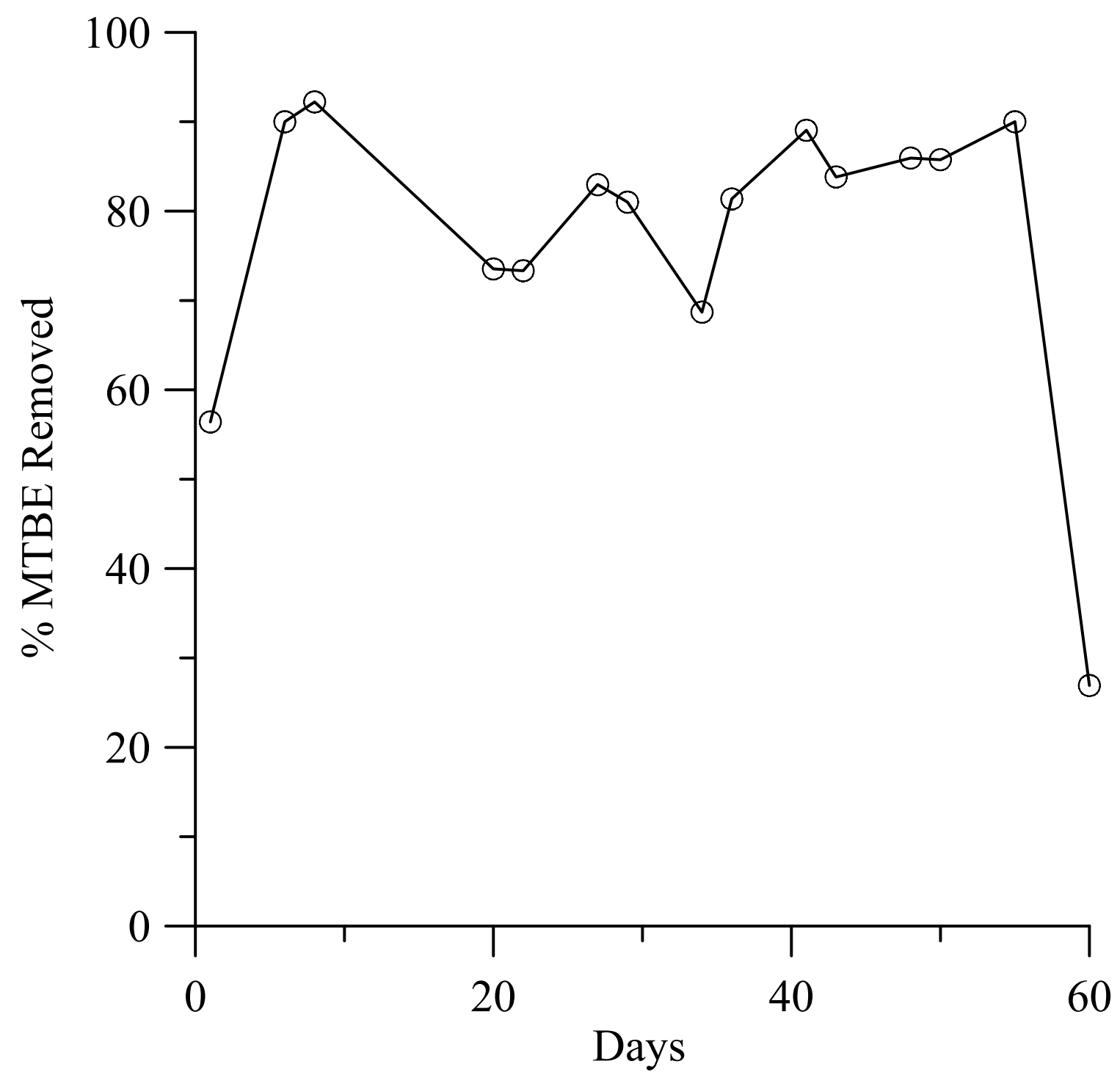


Figure 4: Accumulation of iron on GAC bed material during the third field trial (FT3).

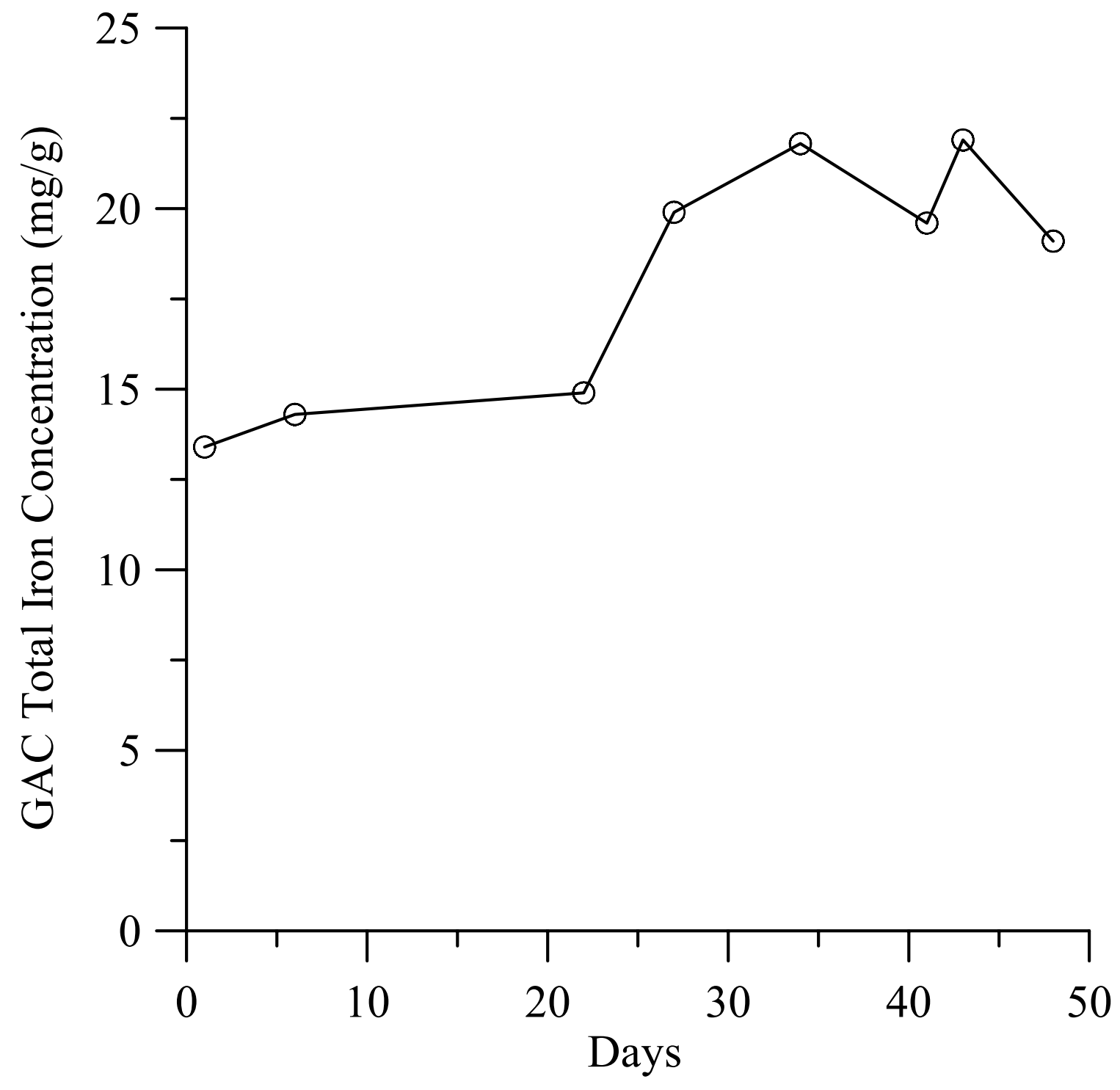


Figure 5: Removal of o-xylene as a function of o-xylene loading by pilot reactor

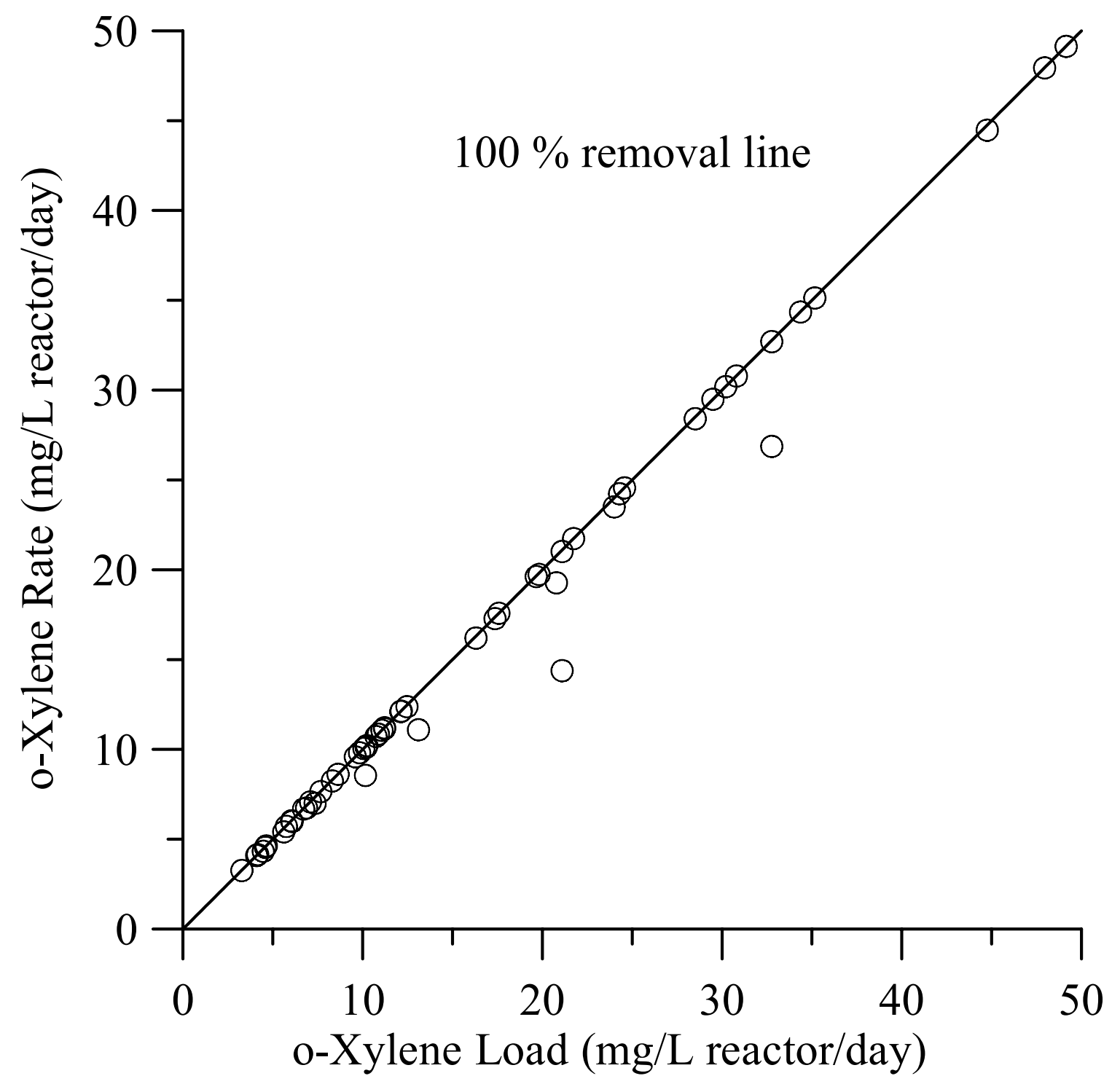


Figure 6: Removal of benzene as a function of benzene loading by pilot reactor

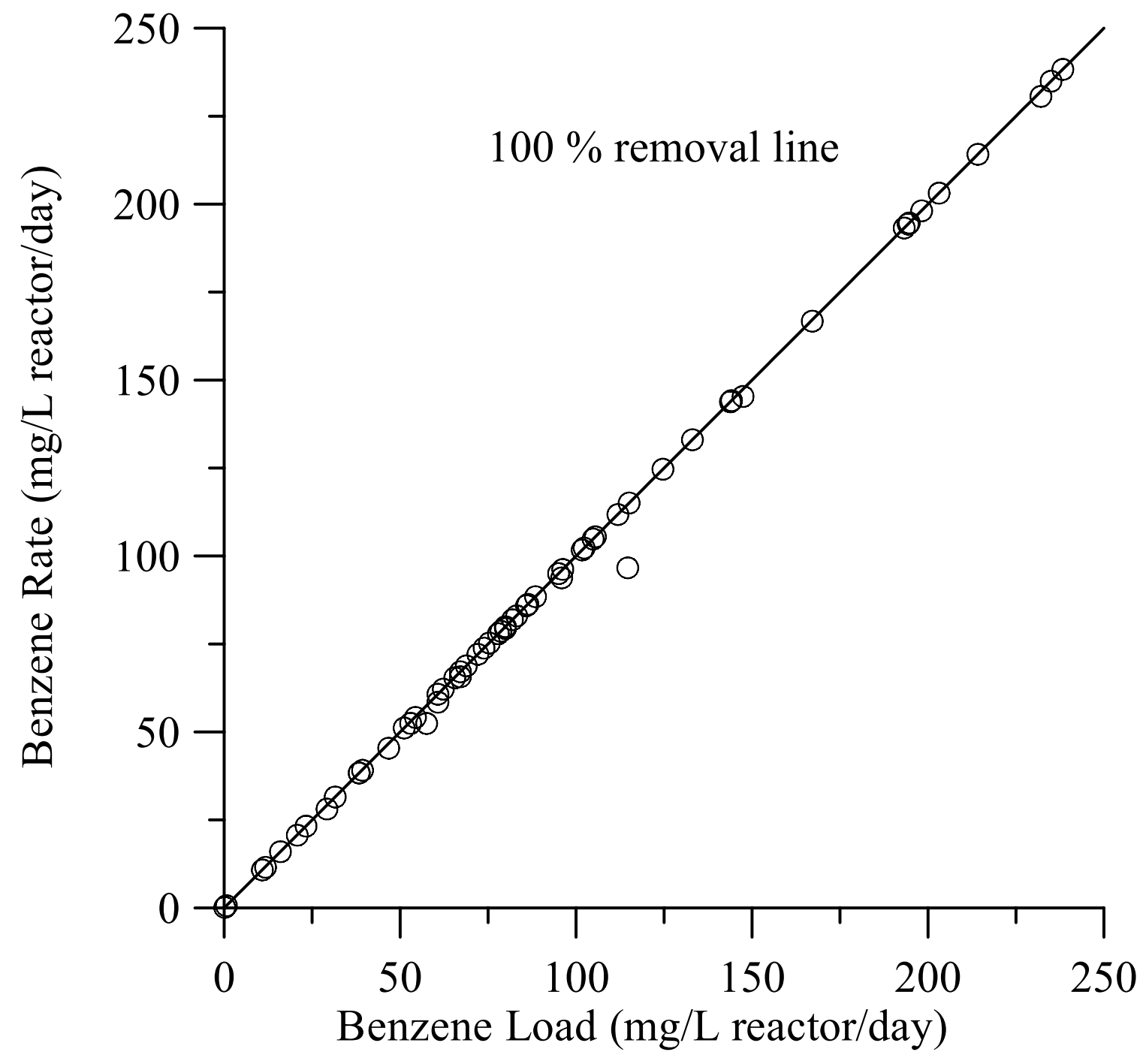


Figure 7: Removal of purgable TPH as a function of purgable TPH loading by pilot reactor

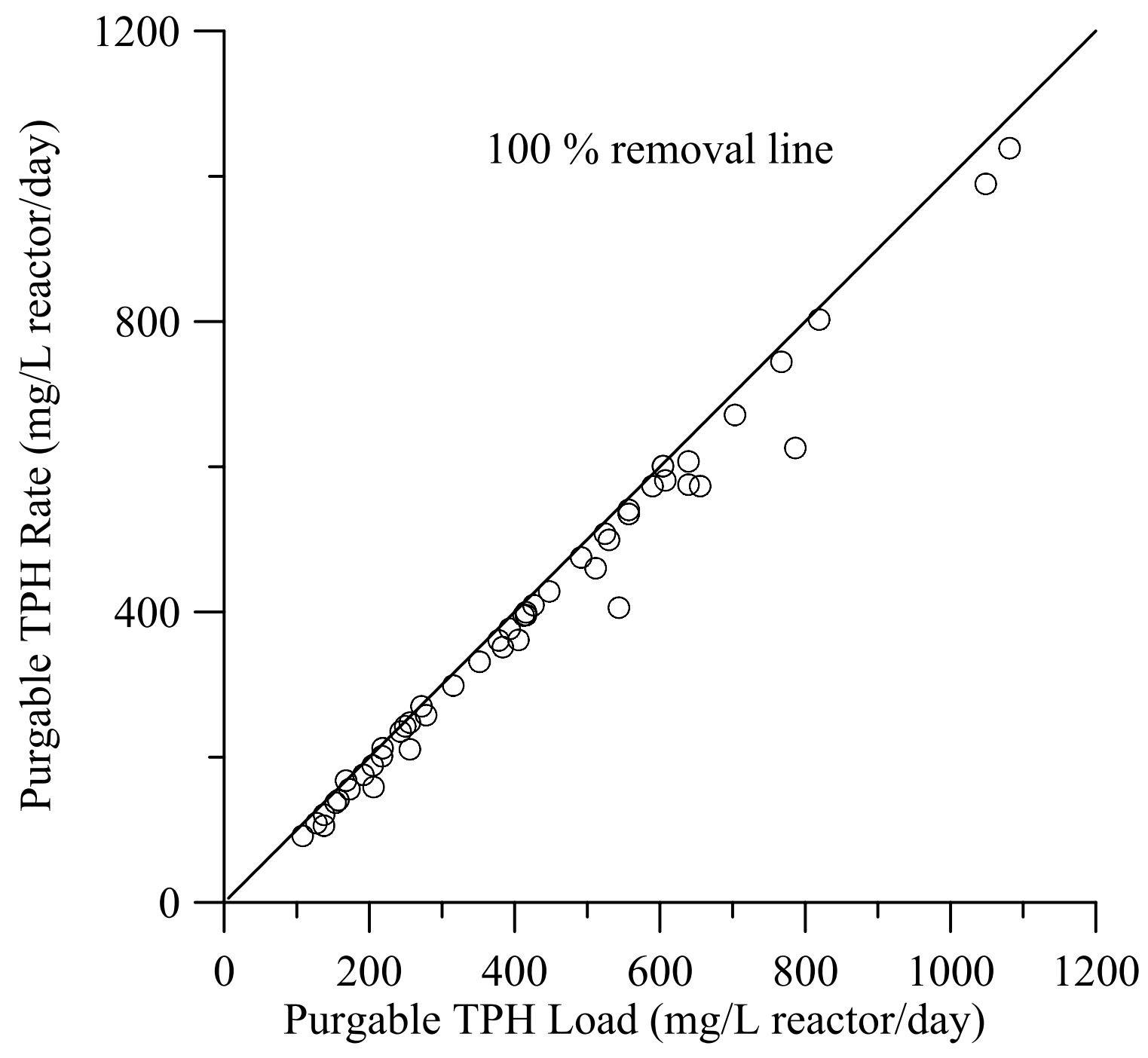


Figure 8: Removal of MTBE as a function of MTBE loading by pilot reactor

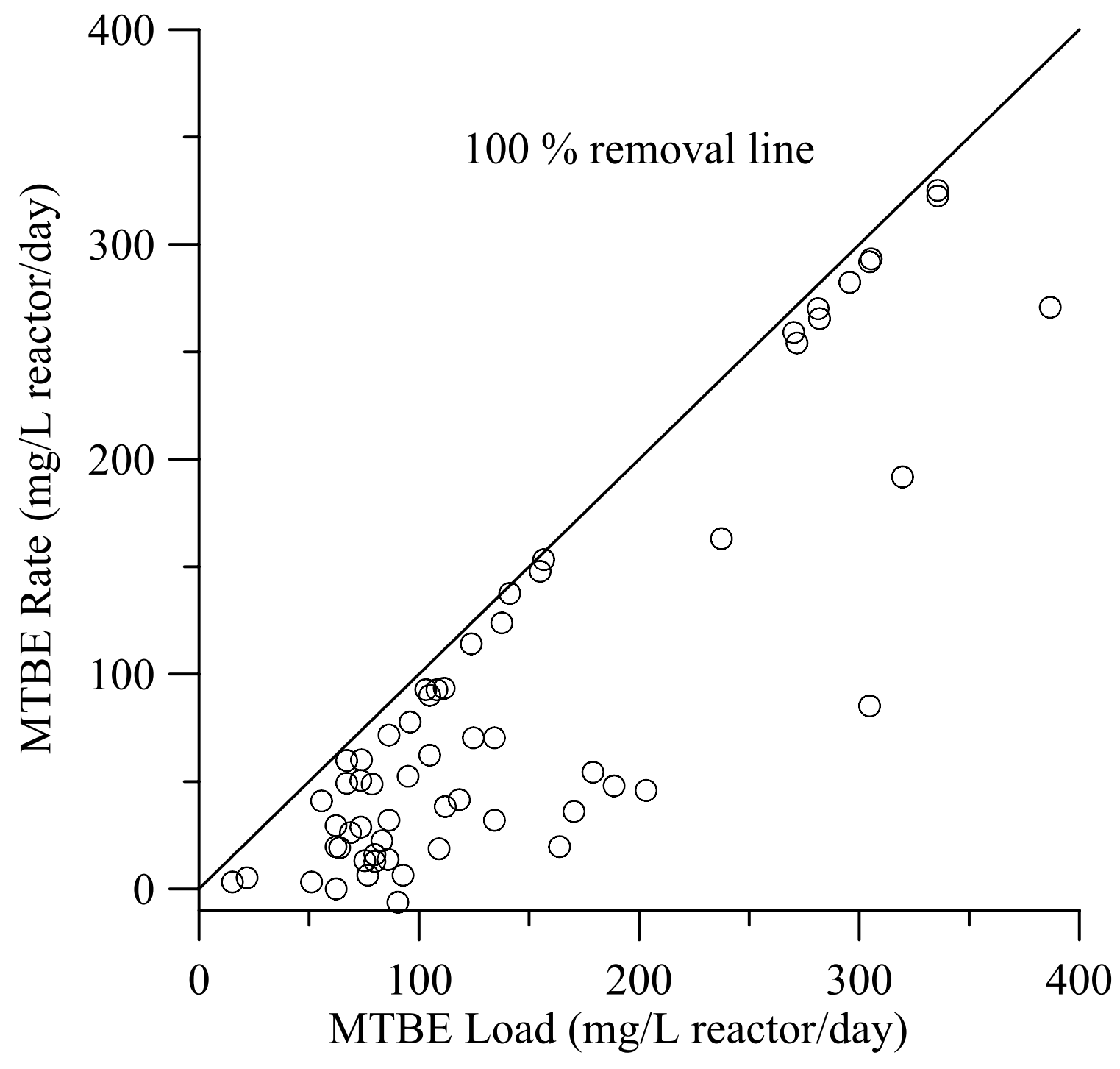


Figure 9: Relationship between MTBE treatment efficiency and protein content of the bed material.

Protein content is a measurement of biofilm formation of the granular activated carbon

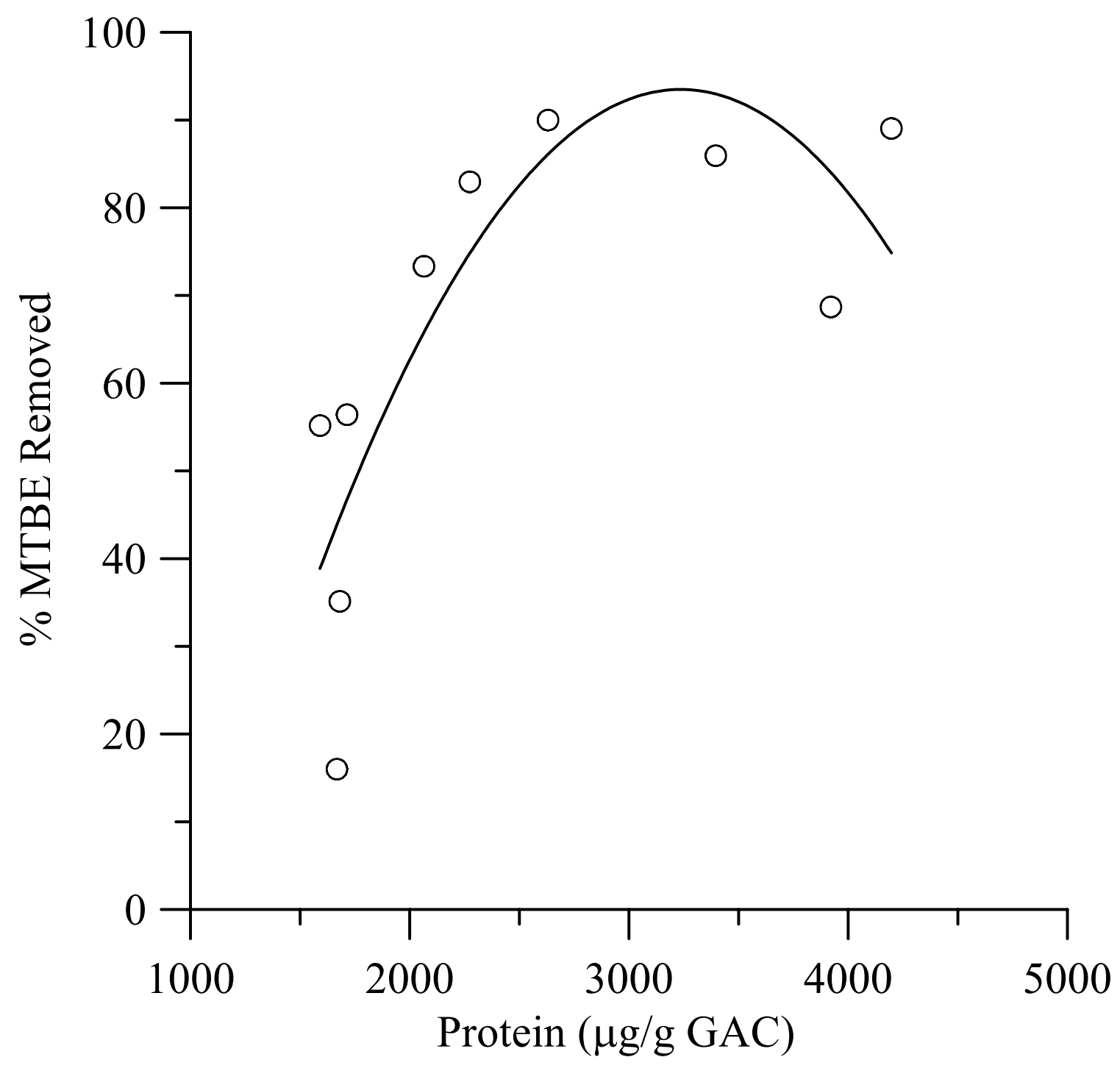


Figure 10. Purgable TPH loading by protein and MTBE efficiency

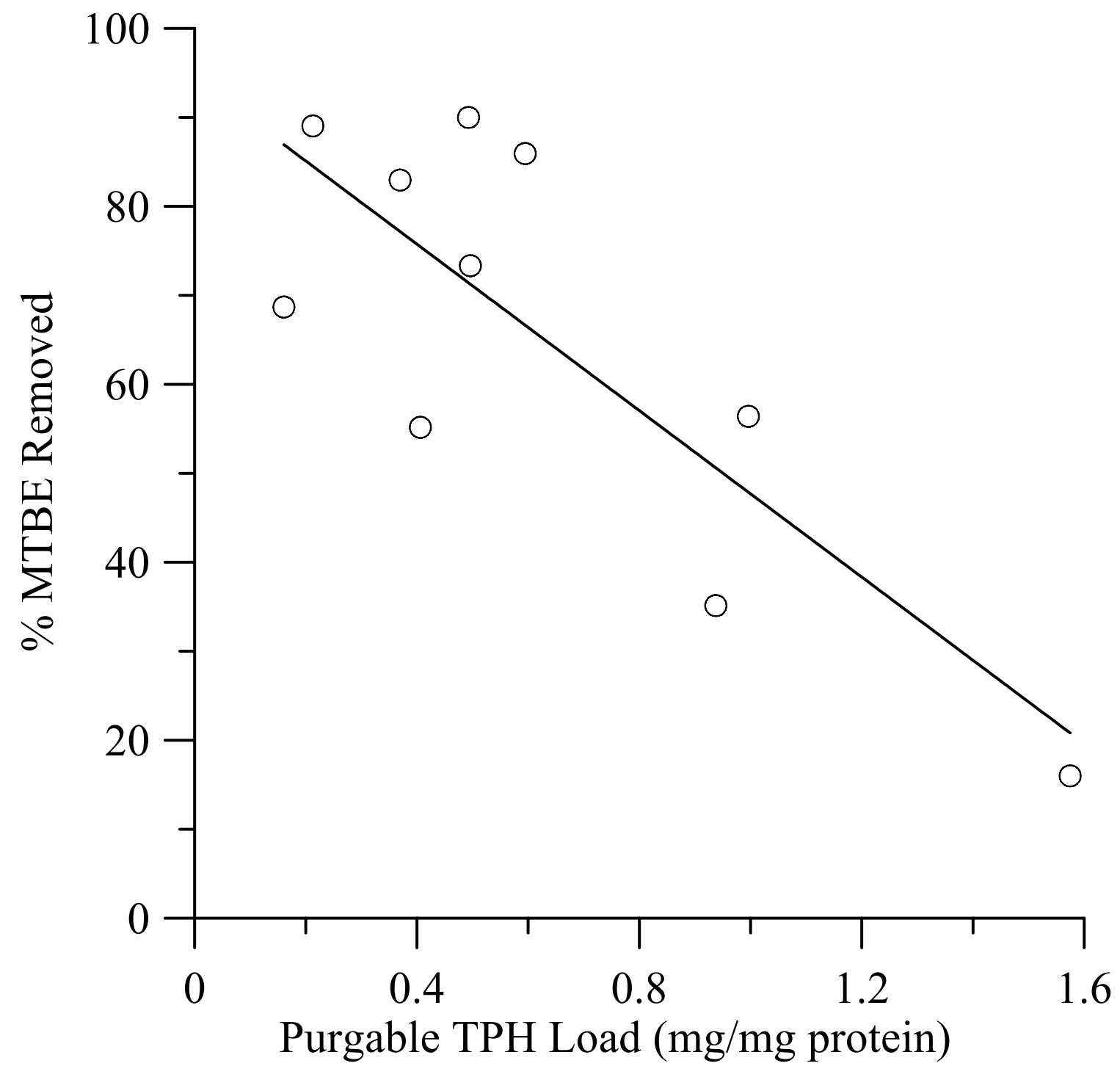


Figure 11. Toluene loading by protein and MTBE efficiency

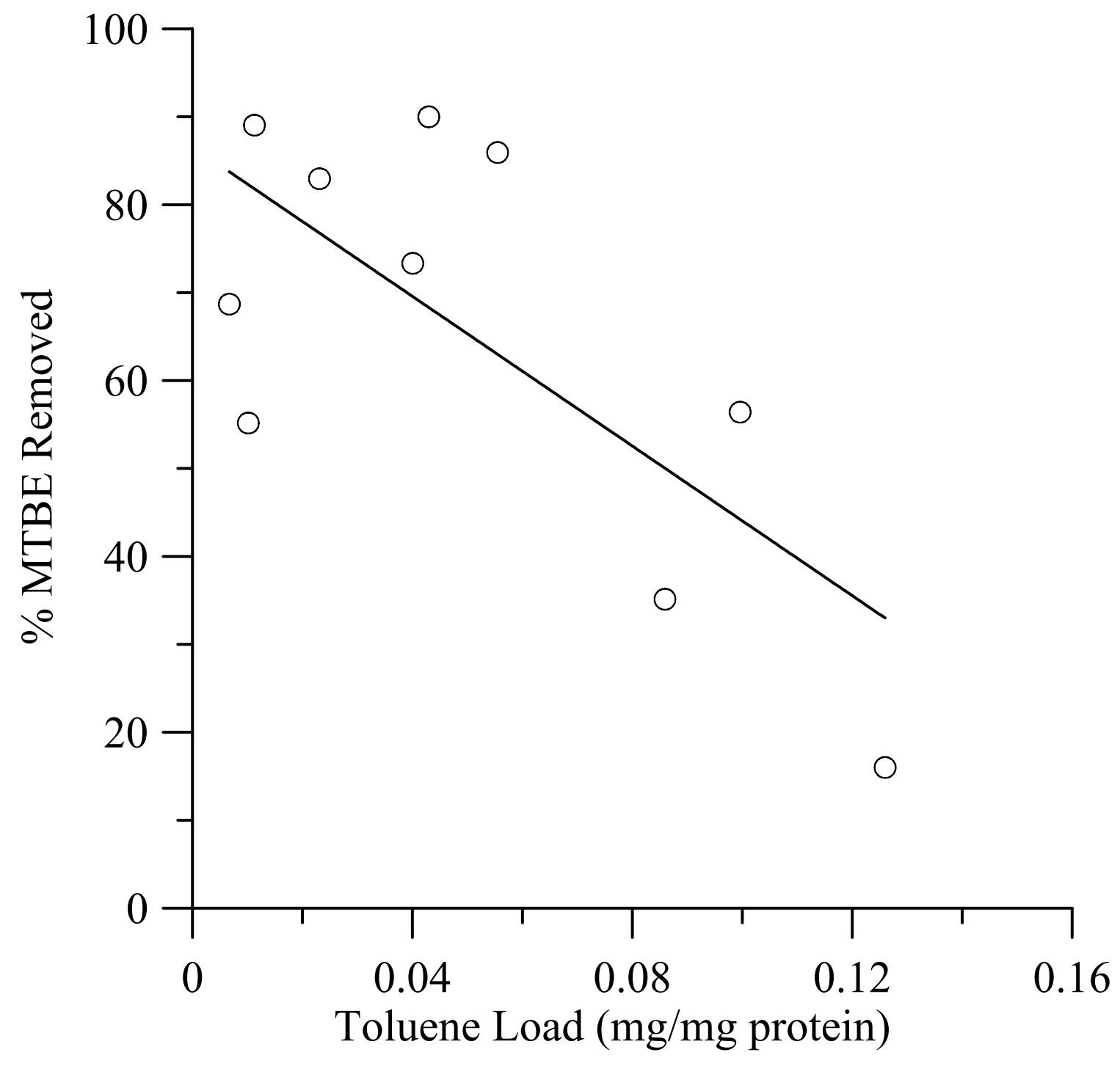


Figure 12: Relationship between MTBE treatment efficiency and effluent $\mathrm{pH}$ during field trials.

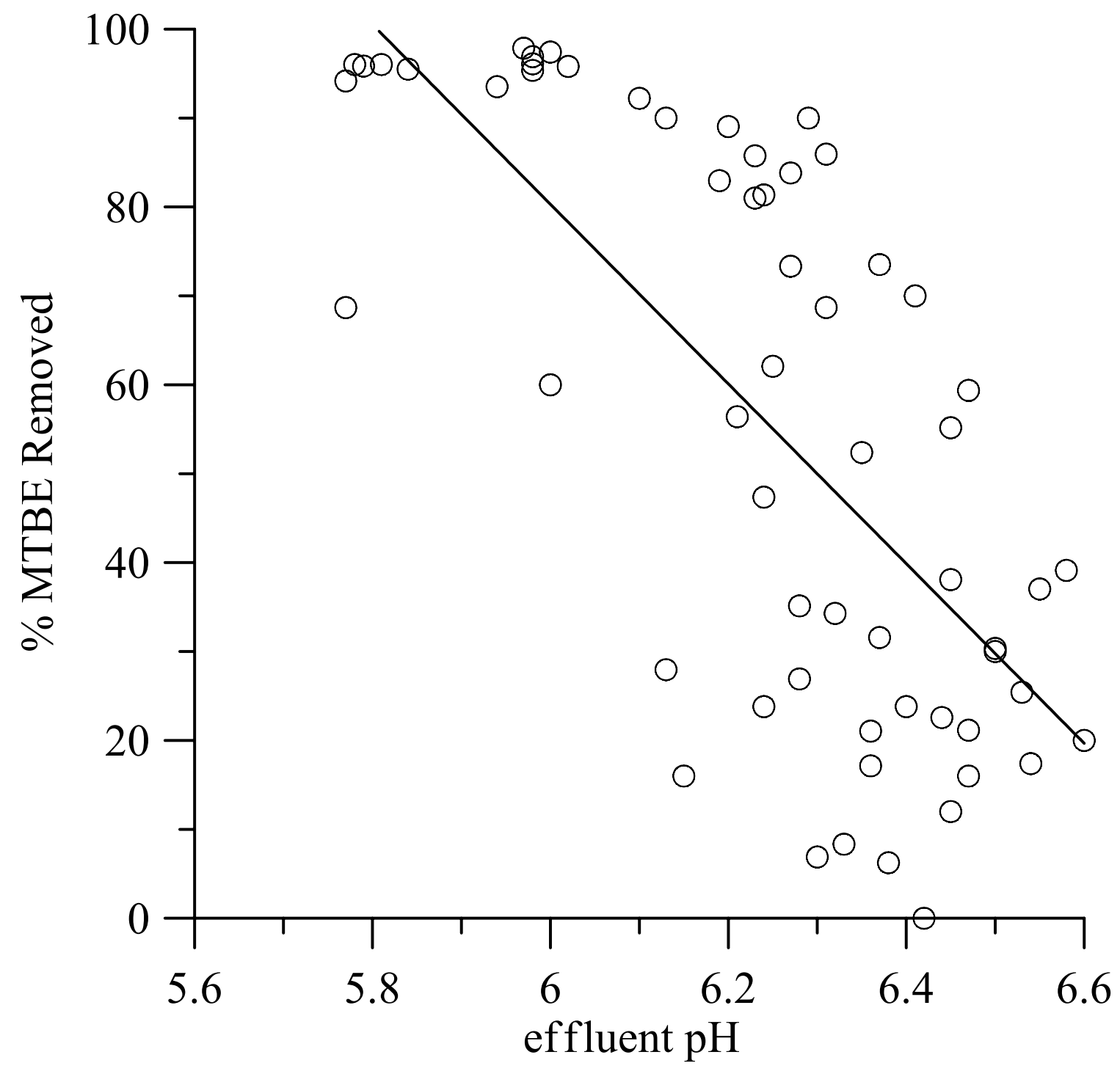


Figure 13: Relationship between effluent $\mathrm{pH}$ and bed height.

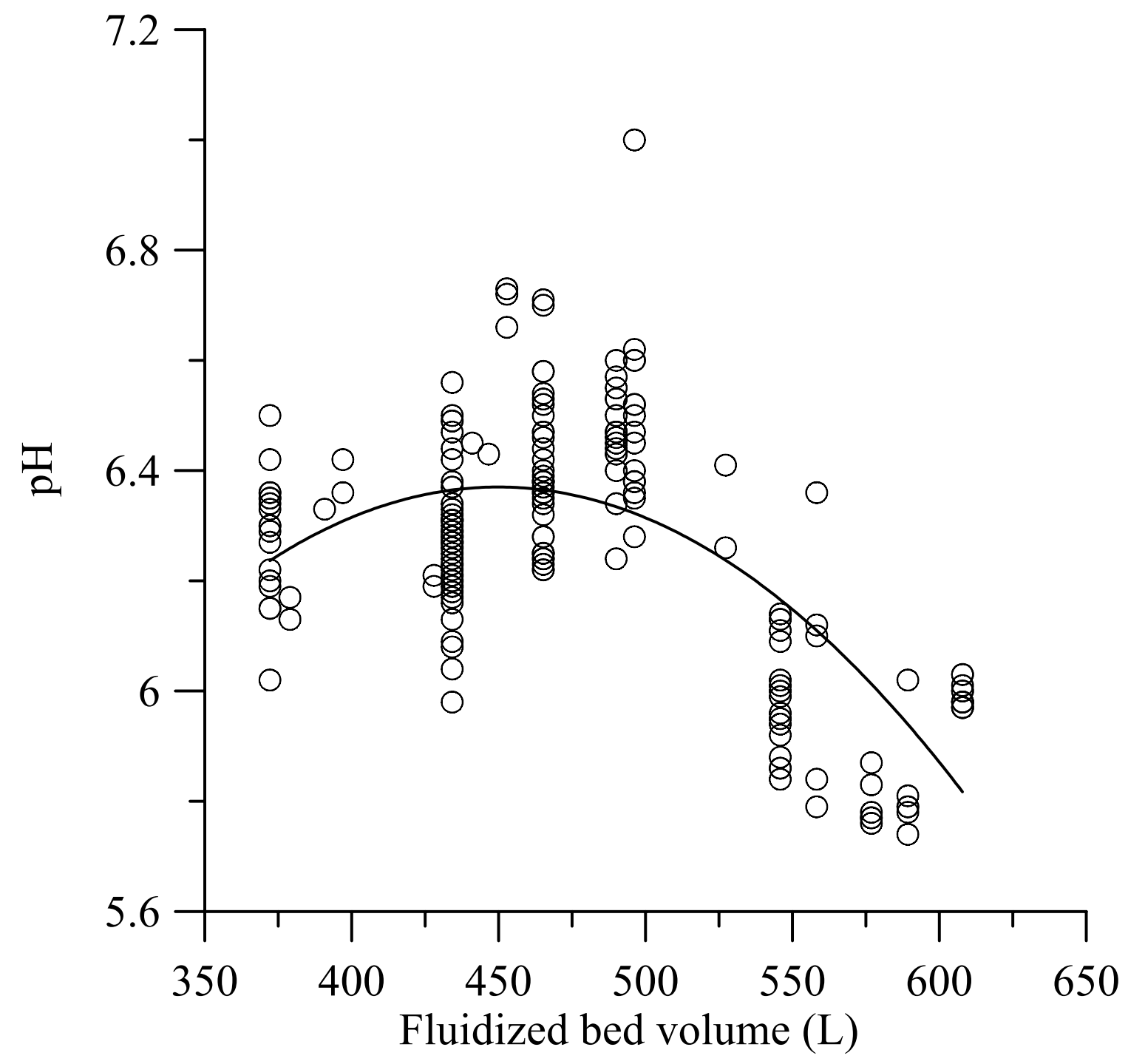

